This is an Accepted Manuscript of an article published by Taylor \& Francis in The Journal of Culinary Science and Technology on 10 Feb, 2019, available online: https://www.tandfonline.com/doi/full/10.1080/15428052.2019.1657336

\title{
EFFECTIVENESS OF THREE FOODSERVICE EQUIPMENT TRAINING INTERVENTIONS FOR FOOD AND NUTRITION STUDENTS
}

Tiffany C. Frieson ${ }^{1}$, Katie R. Miner ${ }^{1}$, Robert Haggert ${ }^{1}$, and Katie N. Brown ${ }^{2}$

1. University of Idaho, Moscow, ID, USA

2. Utah State University, Logan, UT, USA

\begin{abstract}
This study evaluated students' $(N=65)$ reported knowledge, competence, and comfort in using foodservice equipment, as well as confidence in training others after completing one of the following interventions: 1) two food/nutrition courses, and foodservice supervised practice rotations, 2) equipment introduction, and competency exam, and 3) equipment training, practice lab, and competency exam. Foodservice operations and dietetics programs should consider implementing Intervention 3 because there was a significant increase in knowledge, competence, comfort, and confidence using equipment from pre- to post-intervention, it yielded the highest post-intervention scores, and most students received $>86 \%$ for their actual skill.
\end{abstract}

Word Count of the Manuscript: 4,691

Key Words: Foodservice Management, Hospitality Management, Culinary Education 


\section{INTRODUCTION}

Training is key to a successful foodservice operation (Okeiyi, Finley, \& Postel, 1994). Training is defined as "the process of learning the skills you need to do a particular job or activity" ("Training," n.d.). The National Restaurant Association emphasizes the need for employees and managers to have training on kitchen equipment to ensure that they know how to correctly operate, clean, and perform preventative maintenance on all pieces of equipment ("National Restaurant Association, Manage My Restaurant," n.d.). Lack of employee training can cost foodservice operations thousands of dollars if improper use of equipment shortens the equipment's service life (White, 2012). If users are not properly trained, they are at risk for injuring themselves or others (Sinclair et al., 2003), and they are not getting the full use of the equipment (White, 2012). Training should be tailored to each specific piece of equipment to ensure employees can perform all necessary tasks (White, 2012). Training for quantity foodservice equipment (large scale commercial kitchen equipment that is used for preparing food for large amounts of people) (Payne-Palacio \& Theis, 2016) is especially important because 
users are less likely to have prior experience using the equipment. Equipment training is important and emphasized for foodservice operations, and is a competency for dietetic students ("ACEND Accreditation Standards for Nutrition and Dietetics Coordinated Programs," 2016); however, there is a lack of research and documented studies on the effectiveness, perceptions, attitudes towards training, and the transfer of training to the workplace (Rodríguez \& Gregory, 2005).

Results from studies of food safety training suggest the benefit of training, and identify effective training methods. Multiple studies reported training resulted in significant knowledge changes (Costello, Gaddis, Tamplin, \& Morris, 1997 \& Park, Kwak, \& Chang, 2010 \& Sinclair et al., 2003 \& Sparkman, Briley, \& Gillham, 1984). However, changes in behavior were less common (Sparkman et al., 1984). Park et al. (2010) noted no behavior changes in employee practice or sanitation after training, this could be because no hands-on training was available. The Social Cognitive Theory and the Social Leaning Theory can be applied to the concept of training as self-efficacy is increased through mastery experiences, such as hands-on training (Bandura, 1988). Hands-on training programs contribute towards the enhancement of employees' skills and knowledge, and encourage changes in attitude and behaviors (Medeiros, Cavalli, Salay, \& Proença, 2011 \& Park, et al., 2010).

Both Scotland High School and the U.S. Army Quartermaster Corps and Quartermaster School in Fort Lee, Virginia have good training programs in practice and are great examples of what a good training program can look like; however, they have not been evaluated or studied. Steve Dibble, a culinary instructor at Scotland High School, demonstrates how equipment works, starting from how to turn units off and on, and demonstrating how to take it apart and 
put it back together (White, 2012). Dibble then watches the students perform these tasks until they are comfortable and perform the jobs properly (White, 2012). The U.S. Army

Quartermaster Corps and Quartermaster School in Fort Lee, Virginia offers an entry-level foodservice specialist course which is taken by approximately 4,000 soldiers and marines annually (“U.S. Army Quartermaster Corps and Quartermaster School, Fort Lee, Virginia," 2013). The course provides extensive hands-on training with the foodservice equipment they will be using at their work stations ("U.S. Army Quartermaster Corps and Quartermaster School, Fort Lee, Virginia," 2013). Participants in the course take a written exam and are evaluated using the equipment ("U.S. Army Quartermaster Corps and Quartermaster School, Fort Lee, Virginia," 2013). Upon completion of the course the participants have gained experience, knowledge, and confidence in their ability to operate and perform tasks on the equipment ("U.S. Army Quartermaster Corps and Quartermaster School, Fort Lee, Virginia," 2013).

There is limited research and validated foodservice equipment training programs available in the foodservice sector and in dietetics education. In addition, few studies evaluated the effect that training had on actual performance (Rodríguez \& Gregory, 2005). For these reasons further research on the effectiveness of quantity foodservice equipment training is necessary. This study evaluated three foodservice equipment training strategies in terms of nutrition and dietetic students' reported knowledge, competence, comfort in using foodservice equipment, and confidence in training others to use foodservice equipment. Actual skill was assessed in Intervention 3. Therefore, the purpose of this study was to compare nutrition and dietetic students' knowledge, competence, and comfort in using foodservice equipment, as well as confidence in training others to use foodservice equipment before and after completing one 
the following interventions: 1) completion of one quantity food equipment and production course and one management course, including an equipment introduction walk through, and supervised practice rotations in campus foodservice establishments, 2) equipment introduction walk through, optional open labs times, and an equipment competency exam, and 3) extensive equipment training, optional open labs times, practice lab, and an equipment competency exam.

\section{METHODS}

This quasi-experimental study assessed three different iterations of equipment training as part of a foodservice management course. In this study, each iteration is described as an intervention. These three different interventions were implemented over the course of three years: 2013-2014, 2014-2015, and 2015-2016. All three interventions aimed to increase students' knowledge, competence, comfort level, and confidence in training others to use quantity foodservice equipment on all the following fourteen pieces of equipment: combination oven/steamer, cook/hold/smoke/oven, commercial microwave, convection oven, slicer, steamjacketed kettle, tilting-braising pan, 20 and 60 quart mixers, dishwasher, combination microwave/convection oven, dice (food processor), gas range, and salamander broiler. The Institutional Review Board (IRB) at one university in the Pacific Northwest certified this project as exempt.

\section{Participants}

Participants were food and nutrition students including dietetic students enrolled in a quantity food equipment and production course at one university in the Pacific Northwest. All participants in Intervention 1 were dietetic students. 


\section{Interventions}

There were three interventions aimed at increasing students' knowledge, competence, comfort level, and confidence in training others to use food service equipment. Refer to Table 1 to see the components that were in each intervention.

Intervention 1. Intervention 1 included the completion of one quantity food equipment and production course: Family and Consumer Science Quantity Food Production and Equipment, and one management course: Family and Consumer Science Food Systems Management. The quantity food course explored food production in large volume, and selection and use of institutional quantity foodservice equipment. Students completed an equipment evaluation assignment, in which they researched two different brands of the same piece of quantity foodservice equipment. Students evaluated the equipment comparing a number of factors: cooking capacity, dimensions, material, utility and plumbing requirements, freight and delivery specifications, installation requirements, warranties, certifications, estimated life of equipment, and cost of equipment. The management course examined institutional organization and management. Students were taken on an equipment introduction walk through of the foods lab by their instructor. A brief foods lab equipment walk through handout was provided, students were to initial off on each piece of equipment. As part both courses students also completed a theme meal project in groups of three to four students. The theme meal project required students to develop and prepare a lunch meal to be served to approximately 25 guests; therefore, students utilized the quantity foodservice equipment in the foods lab. Equipment manuals were available to students for review in the foods lab. Participants were all in the Coordinated Program in Dietetics (CPD) and also completed 
supervised practice rotations in campus foodservice establishments. Students had the opportunity to work with chefs and kitchen staff on food preparation and cooking, using quantity foodservice equipment.

Intervention 2. Intervention 2 involved an equipment introduction walk through, optional open lab times, and an equipment competency exam. Intervention 2 students were enrolled in Family and Consumer Science Quantity Food Production and Equipment course; the interventions took place in the class. In class students were taken on an equipment introduction walk through by the instructor. Students were introduced to the fourteen pieces of quantity foodservice equipment. During the open lab times, students were able to ask the instructor questions on the equipment. Open lab times were optional for students to attend, but highly encouraged to be prepared for the exam. The equipment manuals were available to students on-line and in the foods lab. To assess the validity and clarity of the exam, the equipment competency exam was pilot tested before participants in Intervention 2 took the exam. Three students not enrolled in the Quantity Food Production and Equipment course piloted the exam. Students then took the practical equipment exam to demonstrate competency using all the pieces of equipment. The exam was completed independently; however, two other students were also completing their exam at the same time. Only dietetic students had completed some supervised practice rotations in campus foodservice establishments at the time of the equipment competency exam.

Intervention 3. Intervention 3 consisted of extensive equipment training, optional open lab times, a practice lab, and an equipment competency exam. Intervention 3 students were enrolled in Family and Consumer Science Quantity Food Production and Equipment course; the 
interventions took place in the class. Refer to Table 2 to see a timeline of when the training, practice lab, and equipment exam took place. Before taking the exam students attended a twohour, extensive foodservice equipment training in small groups (3-4 people). The instructor pilot tested the training to one nutrition professor before implementation. During the training the instructor explained and demonstrated how to turn on, operate, clean, and turn off each piece of equipment. Students then completed the same tasks. This was done for each piece of equipment. Students were given an equipment training note sheet to fill out during the training. Students received hands-on experience using all the quantity equipment in the foods lab. The instructor used a note sheet while proving the training, making sure each training session covered all the same material. A scribe was present at each training session to make sure that the training was consistent from session to session. Students also had the opportunity to attend open lab times, in which they could go through the steps of operating each piece of equipment. Students participated in a two-hour practice lab in the foods lab. The practice lab allowed students to cook with five pieces of equipment they felt least comfortable with after receiving the training. When students finished their practice lab they were given the opportunity to review the steps of using each piece of equipment and review the manuals, before leaving they completed a self-reflection assignment. The equipment manuals were available to students on-line and in the foods lab. The practice lab was completed independently; however, one other student was also completing their practice lab at the same time. Before Intervention 3 took the exam two nutrition professors and two students not enrolled in the Quantity Food Production and Equipment course piloted tested the exam twice. Students then took the practical equipment exam to demonstrate competency using all the 
pieces of equipment. Working independently, two students completed their exam at the same time. During the exam the instructor assessed the students' ability to operate the equipment correctly. Through observation, the instructor assessed each students' actual skill on each piece of equipment. Only dietetic students had completed some supervised practice rotations in campus foodservice establishments at the time of the equipment competency exam.

\section{Foodservice Equipment Survey}

Retrospective pre- and post-intervention surveys collected demographic information as well as students' knowledge, competence, comfort using each piece of foodservice equipment, and confidence level in training others. Participants rated their responses on a 4-point scale ranging from not knowledgeable to very knowledgeable, etc. In Interventions 1 and 2, participants answered these questions for two time periods: before and after the intervention. In Intervention 3, participants answered these questions for three time periods: before the intervention, after participating in a practice lab, and after completing an equipment competency exam.

\section{Survey Administration Procedures}

All surveys were administered using Qualtrics, an online survey software (Qualtrics Research Suite (2014) [Computer software]. Provo, UT: Qualtrics, LLC.). For Intervention 1, participants received an email invitation to participate in an on-line retrospective pre- and postintervention survey after the courses had ended. For Interventions 2 and 3, participants were invited in class to participate; they completed the retrospective pre- and post-intervention survey following completion of the equipment competency exam. Participants in Intervention 
3 took an additional survey after participating in a practice lab and training, but before the equipment exam.

\section{Data Analysis}

Statistical significance was set at $p<0.05$ for all tests. SPSS Statistics (IBM Corp.

Released 2011. IBM SPSS Statistics for Windows. Version 22. Armonk, NY: IBM Corp) was used to complete the analysis.

Interventions 1, 2, and 3. Average scores across all pieces of equipment were calculated for knowledge, competence, comfort, and confidence in training others to use the foodservice equipment. Percent of students who had prior experience using each piece of quantity foodservice equipment was calculated. To test for normality, the Shapiro-Wilk test was conducted. This test compared the shape of the sample distribution to the shape of a normal curve. The significance value $(p)$ was below 0.05 for pre- and post-intervention responses related to knowledge, competence, comfort level, and confidence in training others; therefore, the data significantly deviates from a normal distribution. The Levene Statistic tested the null hypothesis that the variances of pre- and post-knowledge, competence, comfort level, and confidence in training others are significantly different. The significance value $(p)$ was greater than 0.05 for pre- and post-intervention responses related to knowledge, competence, comfort level, and confidence in training others; therefore, homogeneity of variance is assumed. Homogeneity of variance means that the variability of pre- and post-knowledge, competence, comfort level, and confidence in training others does not change from Interventions 1, 2, and 3. Due to the non-normal distribution, a non-parametric test was selected and results were reported as medians (ranges). The Jonckheere-Terpsta test was used 
to test for a pattern to the medians of each variable (knowledge, competence, comfort level, and confidence in training others) across interventions in the following order: Intervention 1, Intervention 2, and Intervention 3. This test was conducted to evaluate trends across interventions for pre-intervention, post-intervention, and changes from pre- to postintervention in levels of knowledge, competence, comfort level, and confidence in training others. Post hoc pairwise comparisons were conducted. It was hypothesized that there would be a positive trend for post-intervention levels, and changes from pre- to post-intervention with Intervention 1 having the lowest medians, Intervention 2 having the next highest medians, and Intervention 3 having the highest medians as evidenced by a positive $Z$ score.

Intervention 3. The students were asked to rank each piece of equipment in order their competency from most (1) to least (14) competent. Medians were calculated to determine the pieces of equipment that students were most and least competent in using. The Friedman's test is a non-parametric test that uses mean ranks to test for differences between groups when the dependent variable being measured is ordinal. A Friedman's test was used to determine if there were differences in overall pre-, post-training, and post-exam knowledge, competence, comfort level, and confidence in training others to use foodservice equipment. Pre-, posttraining, and post-exam knowledge, competence, comfort level, and confidence in training others to use foodservice equipment was ranked for each student, meaning that the lowest score out of pre-, post-training, and post-exam was assigned a rank of 1, then the next highest score was assigned a rank of 2 , and the highest score was assigned a rank of 3 . High scores were associated with higher ranks and lower scores with a lower rank. For each variable (knowledge, competence, comfort level, and confidence in training others) sum ranks were 
calculated for pre-, post-training, and post-exam. Mean ranks were calculated by dividing the sum rank by the total number of students. Each student's actual skill for each piece of equipment was determined by the instructor during the exam. Students were considered competent by demonstrating their ability to complete each task: turn on the equipment, cook with the equipment, clean the equipment, and turn off the equipment. Failure to complete one or more of the tasks resulted in no score for that piece of equipment. Students reported their competence (skill) for each piece of equipment on a scale of 1-4, 1 not competent, 2 somewhat competent, 3 competent, and 4 highly competent. Each student received an actual skill score: pieces of equipment they used correctly out of the total number of pieces of equipment (14). Self-reported competence (skill) score was calculated by diving their response by 4 (indicating highly competent). Spearman correlations were conducted to determine the strength and direction between the actual skill and self-reported competence (skill). A Bland-Altman plot compared the agreement between actual skill to self-reported competence (skill).

\section{RESULTS}

Participants in Intervention $1(n=14)$ were dietetic students, and in Intervention 2 ( $n=$ 25) and Intervention $3(n=26)$ participants were food and nutrition students, including dietetic students.

\section{Interventions 1, 2, and 3}

Intervention 1 had the highest percent of students who had prior experience using quantity foodservice equipment (average 31\%) compared to Interventions 2 and 3 (average $20 \%$ and $14 \%$, respectively). In all three Interventions the highest percentage of students reported prior experience using the dishwasher. The tilting braising pan and salamander broiler 
had the lowest percentage of students' prior use (see Table 3). Intervention 1 had the highest level of all pre-intervention variables. Intervention 3 had the lowest level of all the preintervention variables. The trend for pre-knowledge, competence, comfort level, and confidence in training others decreased from interventions (see Table 4 and Figure 1 ). Intervention 3 had the highest levels of all post-intervention variables, higher than Interventions 1 and 2 (see Table 5 and Figure 2). Post-Intervention scores were not significantly different when comparing Interventions 1 and 2. Intervention 2 was higher in post-confidence in training others, while Intervention 1 was higher in post-knowledge, competence, comfort level. Intervention 3 had the greatest change from pre- to post-intervention changes across interventions (see Table 6 and Figure 3). This was expected as Intervention 3 had the lowest pre- and highest post-variables. Intervention 3 was higher than Interventions 1 and 2 across all variables.

\section{Intervention 3}

On the retrospective pre- and post-intervention survey students indicated that they were most competent using the following pieces of equipment: convection oven, dice (food processor), and dishwasher (see Table 7). Students reported that they were least competent in using the cook hold smoke oven, steam jacketed kettle, and gas range. Results from the Friedman's test indicate that there was a significant increase in knowledge, competence, comfort level, and confidence in training others using each piece of foodservice equipment calculated from pre-intervention to, post-exam (see Table 8).

Actual skill. Eighty-eight percent of students received $86 \%$ or better (maximum $=100 \%$, minimum $=71 \%$ ) on their actual skill. Actual skills from the exam were compared to self- 
reported competence (skill), spearman correlations showed that there were no significant correlations. The Bland-Altman plot showed that there were points plotted on each side of the mean, with one outlier (see Figure 4). This tests identifies possible outliers and differences between the two groups. The $Y$ axis is the difference of the actual skill and the self-reported competence (skill) (difference $=$ actual skill - self-reported competence [skill]). The $\mathrm{X}$ axis is the mean of actual skill and the self-reported competence (skill). The plot reports the upper and lower $95 \%$ confidence limits and mean difference between the two measurements (middle line). Students $(n=13)$ reported a low skill level, but their actual skill level was higher than reported, under reporting. Students $(n=7)$ reported a high skill level, but their actual skill level

was lower than reported, over reporting. Students $(n=5)$ reported a skill level and their actual skill level matched their reported.

\section{DISCUSSION}

These results indicate that there were improvements in knowledge, competence, and comfort in using foodservice equipment, as well as confidence in training others following each of the interventions. Students in Intervention 3 had the highest post-intervention score, despite the fact that students in Intervention 1 had the highest pre-intervention score and highest amount of prior experience using quantity foodservice equipment. With more training and experience from Interventions 1, 2 and 3, students' levels of knowledge, competence, and comfort in using foodservice equipment, as well as confidence in training others to use foodservice equipment were higher. Fifty percent or fewer had prior experience on most pieces of equipment. In all three interventions, the highest percentage of students had used a dishwasher prior to the intervention, while the tilting braising pan and salamander broiler had 
the lowest percentage of students' prior use. The tilting braising pan and salamander broiler were less common in foodservice establishments.

The results of this study add to body of research as actual skill was assessed; not all training studies evaluated actual behavior. Students in Intervention 3 received an actual skill score, all students received an overall passing score. Most students received $86 \%$ or better. Following Intervention 3 (extensive equipment training, optional open labs times, practice lab, and an equipment competency exam) students were competent operating the equipment. It was determined that most students under report on their skill level to their actual skill level. If students were not certain of their ability to perform a task, this may negatively affect their competence when operating foodservice equipment. Students were operating the equipment correctly; however, their reported comfort level was low. This was possibly due to the fact it was an exam and students are typically stressed in exams.

The equipment training in this study was standardized and may be a more effective way to train students rather than supervised practice in campus foodservice establishments. Supervised practice rotations may differ from one dietetic student to the next at the exact same rotation, due to the daily variation in production tasks and kitchen staff. Also, supervised practice experience may differ from one university to another depending on what is available at the campus foodservice establishment(s).

Interventions 2 and 3 in this study followed good hands-on training practices, such as having the instructor demonstrating how to turn on and off, operate, and clean each piece of equipment then having each student repeat the same tasks for each piece of equipment ("U.S. Army Quartermaster Corps and Quartermaster School, Fort Lee, Virginia," 2013 \& White, 2012). 
In the current study for Interventions 2 and 3, students had hands-on experience as they took a practical exam on the equipment ("U.S. Army Quartermaster Corps and Quartermaster School, Fort Lee, Virginia," 2013). Intervention 3 allowed for mastery experiences during the practice lab and extensive equipment training. The findings from this study aligned with the Social Learning Theory and the Social Cognitive Theory, as self-efficacy was increased and desired behaviors were achieved.

While this study provides findings regarding the effectiveness of foodservice equipment training, certain limitations exist. The low sample size of Intervention 1 presents a limitation; this may have been because dietetic students were invited by email to complete a survey after the courses had already ended. A further limitation was that actual skills were only reported for Intervention 3; therefore, comparison between skills from intervention to intervention cannot be established. Actual skills were rated on a scale from 1-14, it would have made for an easier comparison on a Likert scale from 1-4, since the survey scale was from 1-4. Additionally, the participants in all interventions were mostly female and from one university in the Pacific Northwest. In Interventions 2 and 3 only a few of the dietetic students completed supervised practice rotations in campus foodservice establishments, this was not controlled for in the analysis. The instructor for the equipment training interventions was the same for all three interventions. During Intervention 1 the instructor was enrolled as a student in Quantity Food Production and Equipment, and Food Systems Management, while working on this equipment research as part of an undergraduate directed study course. During Interventions 2 and 3 the instructor was a student in the Coordinated Program in Dietetics (CPD), and was working on this study for graduate thesis research. Students may have treated their intervention experience 
and survey participation less seriously as the instructor was a classmate and not a professor; however, professor oversight and mentorship was provided.

\section{CONCLUSIONS AND APPLICATIONS}

This study compared nutrition and dietetic students' knowledge, competence, and comfort in using foodservice equipment, as well as confidence in training others to use foodservice equipment after completing one the following interventions. These findings will allow for further research on this topic, such as monitoring the actual skill from after the time of the equipment exam. Future research for dietetic students could evaluate the effectiveness of supervised practice for training students on foodservice equipment among different universities. This same study could also be carried out at another university or a foodservice operation that has a quantity foodservice equipment. This research highlights the importance of foodservice equipment training for food and nutrition students, including dietetic students and also for foodservice operations and employees. Though further research should be done, this study gives good examples of a number of training options as knowledge, competence, and comfort in using foodservice equipment, as well as confidence in training others to use foodservice equipment increased after all interventions. Foodservice operations and dietetic programs should consider implementing Intervention 3 because it resulted in the greatest amount of change due to the extensive equipment training, and was verified with actual skill.

\section{REFERENCES}

ACEND Accreditation Standards for Nutrition and Dietetics Coordinated Programs. (2016). Accreditation council for education in nutrition and dietetics. Retrieved September 3, 2016, from http://www.eatright.org/ACEND. 
Bandura, A. (1988). Organizational applications of social cognitive theory. Australian Journal of Management, 13, 275-302.

Costello, C., Gaddis, T., Tamplin, M., \& Morris, W. (1997). Evaluating the effectiveness of two instructional techniques for teaching food safety principles to quick service employees. Journal of Foodservice, 10(1), 41-50.

Medeiros, C. O., Cavalli, S. B., Salay, E., \& Proença, R. P. (2011). Assessment of the methodological strategies adopted by food safety training programs for food service workers: A systematic review. Food Control, 22(8), 1136-1144.

National Restaurant Association, Manage My Restaurant. (n.d.). Training staff on kitchen equipment. Retrieved September 6, 2016, from http://www.restaurant.org/ManageMy-Restaurant/Workforce-Management/Training-and-Onboarding/Training-staff-onkitchen-equipment.

Okeiyi, E., Finley, D., \& Postel, R. (1994). Food and beverage management competencies: Educator, industry, and student perspectives. Journal of Hospitality \& Tourism Educator, 6, 37-40.

Park, S., Kwak, T., \& Chang, H. (2010). Evaluation of the food safety training for food handlers in restaurant operations. Nutrition Research and Practice, 4, 58-68.

Payne-Palacio, J., \& Theis, M. (2016). Foodservice management: Principles and practices. Boston: Pearson.

Rodríguez, C. M., \& Gregory, S. (2005). Qualitative study of transfer of training of student employees in a service industry. Journal of Hospitality \& Tourism Research, 29, 42-66.

Sinclair, R., Smith, R., Colligan, M., Prince, M., Nguyen, T., \& Stayner, L. (2003). Evaluation of a safety training program in three food service companies. Journal of Safety Research, 34, 547-558.

Sparkman, A. F., Briley, M. E., \& Gillham, M. B. (1984). Validated food service training manual for supervisors with limited experience. Journal of the American Dietetic Association, 84(12), 1475-1478.

Training. (n.d.). In Cambridge English Dictionary.com. Retrieved September 6, 2016, from http://dictionary.cambridge.org/us/dictionary/english/training.

U.S. Army Quartermaster Corps and Quartermaster School, Fort Lee, Virginia. (2013). Basic food service training division. Retrieved September 10, 2016, from http://www.quartermaster.army.mil/jccoe/Joint_Culinary_Training_Directorate/basic_s kills/iet_basic.html. 
White, L. (2012). The bottom line on equipment training. Foodservice Equipment \& Supplies. Retrieved August 28, 2016, from http://www.fesmag.com/features/foodserviceissues/9883-the-bottom-line-on-equipment-training.

\section{TABLES AND FIGURES}

Table 1. Intervention methods for all three Interventions.

(Shaded box indicates inclusion in interventions.)

\begin{tabular}{|c|c|c|c|}
\hline Intervention & 1 & 2 & 3 \\
\hline \multicolumn{4}{|l|}{$\begin{array}{l}\text { Dietetic students } \\
\text { Students in the Coordinated Program in Dietetics }\end{array}$} \\
\hline $\begin{array}{l}\text { Supervised practice in campus foodservice } \\
\text { establishments } \\
\text { Dietetics students worked with chefs and kitchen } \\
\text { staff on food preparation and cooking, using } \\
\text { quantity foodservice equipment in campus } \\
\text { foodservice establishments }\end{array}$ & & $\begin{array}{l}19 / 25 \\
\text { students } \\
\text { completed } \\
6-7 \\
\text { rotations }\end{array}$ & $\begin{array}{l}19 / 26 \\
\text { students } \\
\text { completed } \\
2-6 \\
\text { rotations }\end{array}$ \\
\hline \multicolumn{4}{|l|}{$\begin{array}{l}\text { Food and nutrition students } \\
\text { Students studying food and nutrition who were not } \\
\text { in the Coordinated Program in Dietetics }\end{array}$} \\
\hline \multicolumn{4}{|l|}{$\begin{array}{l}\text { Currently in a quantity food equipment and } \\
\text { production course }\end{array}$} \\
\hline \multicolumn{4}{|l|}{$\begin{array}{l}\text { Optional open labs } \\
\text { Specific times were scheduled for students to come } \\
\text { to the foods lab and ask the instructor questions } \\
\text { about the equipment, and the review equipment } \\
\text { manuals }\end{array}$} \\
\hline \multicolumn{4}{|l|}{$\begin{array}{l}\text { Equipment competency exam } \\
\text { Practical equipment exam to demonstrate } \\
\text { competency using all the pieces of equipment }\end{array}$} \\
\hline \multicolumn{4}{|l|}{$\begin{array}{l}\text { Extensive equipment training } \\
\text { A two-hour, extensive hands-on foodservice } \\
\text { equipment training in small groups (3-4 people) }\end{array}$} \\
\hline \multicolumn{4}{|l|}{$\begin{array}{l}\text { Practice lab } \\
\text { Students cooked with five pieces of equipment they } \\
\text { felt least comfortable with after receiving the } \\
\text { extensive equipment training }\end{array}$} \\
\hline $\begin{array}{l}\text { Foods lab equipment walk through } \\
\text { Instructor took students on a tour of the foods lab } \\
\text { providing a brief introduction to the equipment, } \\
\text { including the name and use of each piece of } \\
\text { equipment }\end{array}$ & & & \\
\hline
\end{tabular}


Completion of one quantity food equipment and

production course and one management course

Table 2. Timeline of Intervention 3 strategies.

(Shaded box indicates which week the strategy took place.)

\begin{tabular}{|l|l|l|l|l|l|l|l|l|l|l|}
\hline Week & 1 & 2 & 3 & 4 & 5 & 6 & 7 & 8 & 9 & 10 \\
\hline Training & & & & & & & & & & \\
\hline Practice Lab & & & & & & & & & & \\
\hline Exam & & & & & & & & & & \\
\hline
\end{tabular}

Table 3. Student prior experience using the quantity foodservice equipment.

\begin{tabular}{|l|l|l|l|}
\hline Foodservice Equipment & $\begin{array}{l}\text { Intervention 1 } \\
(n=14)\end{array}$ & $\begin{array}{l}\text { Intervention 2 } \\
(n=25)\end{array}$ & $\begin{array}{l}\text { Intervention 3 } \\
(n=26)\end{array}$ \\
\hline Combination Oven/Steamer & $21 \%$ & $8 \%$ & $8 \%$ \\
\hline Cook Hold Smoke Oven & $21 \%$ & $4 \%$ & $4 \%$ \\
\hline Commercial Microwave & $50 \%$ & $24 \%$ & $19 \%$ \\
\hline Convection Oven & $50 \%$ & $20 \%$ & $8 \%$ \\
\hline Slicer & $36 \%$ & $32 \%$ & $23 \%$ \\
\hline Steam Jacketed Kettle & $21 \%$ & $12 \%$ & $4 \%$ \\
\hline Tilting Braising Pan & $14 \%$ & $8 \%$ & $4 \%$ \\
\hline 20 Quart Mixer & $43 \%$ & $28 \%$ & $8 \%$ \\
\hline 60 Quart Mixer & $21 \%$ & $20 \%$ & $12 \%$ \\
\hline Dishwasher & $64 \%$ & $56 \%$ & $69 \%$ \\
\hline $\begin{array}{l}\text { Combination } \\
\text { Microwave/Convection Oven }\end{array}$ & $14 \%$ & $20 \%$ & $8 \%$ \\
\hline Dice (Food Processor) & $14 \%$ & & $8 \%$ \\
\hline Gas Range & $50 \%$ & $36 \%$ & $12 \%$ \\
\hline Salamander Broiler & $14 \%$ & $8 \%$ & $4 \%$ \\
\hline Average & $\mathbf{3 1 \%}$ & $8 \%$ & $\mathbf{1 4 \%}$ \\
\hline
\end{tabular}


Table 4. Trends in pre-intervention knowledge, competence, comfort level, and confidence in training others among Interventions 1, 2, and 3 (Medians and Ranges).

\begin{tabular}{|l|l|l|l|l|l|}
\hline Intervention & 1 & 2 & 3 & $Z$ & $p$ \\
\hline & Pre- & Pre- & Pre- & & \\
\hline Knowledge & $1.64(1.93)$ & $1.29(1.86)$ & $1.14(2.00)$ & -2.875 & 0.004 \\
& $n=13 r$ & $n=25$ & $n=26$ & & $N=64$ \\
\hline Competence & $2.00(1.93)$ & $1.36(2.07)$ & $1.14(1.86)$ & -3.857 & 0.000 \\
& $n=12$ & $n=25$ & $n=26$ & & $N=63$ \\
\hline Comfort Level & $1.93(1.71)$ & $1.43(2.29)$ & $1.14(2.14)$ & -2.243 & 0.025 \\
& $n=12$ & $n=25$ & $n=26$ & & $N=63$ \\
\hline Confidence in & $1.50(1.29)$ & $1.29(3.00)$ & $1.07(1.71)$ & -2.397 & 0.017 \\
training others & $n=9$ & $n=25$ & $n=26$ & & $N=60$ \\
\hline
\end{tabular}

Table 5. Trends in post-intervention knowledge, competence, comfort level, and confidence in training others among Interventions 1, 2, and 3 (Medians and Ranges).

\begin{tabular}{|l|l|l|l|l|l|}
\hline Intervention & 1 & 2 & 3 & $\mathrm{Z}$ & $p$ \\
\hline & Post- & Post- & Post- & & \\
\hline Knowledge & $3.14(1.64)$ & $3.00(2.07)$ & $3.64(3.00)$ & 3.074 & 0.002 \\
& $n=12$ & $n=25$ & $n=25$ & & $N=62$ \\
\hline Competence & $3.00(2.86)$ & $2.79(2.07)$ & $3.57(3.00)$ & 3.414 & 0.001 \\
& $n=13$ & $n=25$ & $n=25$ & & $N=63$ \\
\hline Comfort Level & $3.04(1.21)$ & $2.93(2.79)$ & $3.64(3.00)$ & 2.353 & 0.019 \\
& $n=12$ & $n=25$ & $n=25$ & & $N=62$ \\
\hline Confidence in & $2.71(0.93)$ & $2.86(2.79)$ & $3.57(3.00)$ & 2.928 & 0.003 \\
training others & $n=9$ & $n=25$ & $n=25$ & & $N=59$ \\
\hline
\end{tabular}

Table 6. Trends in pre- to post-intervention changes among Interventions 1, 2, and 3 (Medians and Ranges).

\begin{tabular}{|l|l|l|l|l|l|}
\hline & & & & $Z$ & $p$ \\
\hline & Intervention & Intervention & $\begin{array}{l}\text { Intervention } \\
3\end{array}$ & & \\
& 1 & 2 & 3 & & \\
\hline Knowledge & $1.32(1.86)$ & $1.50(1.79)$ & $2.29(3.00)$ & 4.207 & 0.000 \\
& $n=12$ & $n=25$ & $n=25$ & & $N=62$ \\
\hline Competence & $1.11(1.79)$ & $1.36(1.57)$ & $2.43(3.00)$ & 4.943 & 0.000 \\
& $n=12$ & $n=25$ & $n=25$ & & $N=62$ \\
\hline
\end{tabular}




\begin{tabular}{|l|l|l|l|l|l|}
\hline Comfort Level & $\begin{array}{l}1.04(1.57) \\
n=12\end{array}$ & $\begin{array}{l}1.21(2.00) \\
n=25\end{array}$ & $\begin{array}{l}1.93(3.14) \\
n=25\end{array}$ & 4.070 & $\begin{array}{l}0.000 \\
N=62\end{array}$ \\
\hline Confidence in & $\begin{array}{l}1.00(1.29) \\
n=9\end{array}$ & $\begin{array}{l}1.21(2.79) \\
n=25\end{array}$ & $\begin{array}{l}2.07(3.07) \\
n=25\end{array}$ & 3.616 & 0.000 \\
training others & $n=59$ \\
\hline
\end{tabular}

Table 7. Intervention 3 student participants' reported most and least competent pieces of equipment.

\begin{tabular}{|l|l|l|l|}
\hline Most & Median & Least & Median \\
\hline Convection Oven & 4 & Cook Hold Smoke Oven & 10 \\
\hline Dice & 4 & Steam Jacketed Kettle & 10 \\
\hline Dishwasher & 4 & Gas Range & 10 \\
\hline 20 qt. mixer & 5 & Menumaster & 13 \\
\hline
\end{tabular}

Table 8. Differences in knowledge, competence, comfort level, confidence among pre-, posttraining, and post-exam, Friedman's Test (mean ranks).

\begin{tabular}{|c|c|c|c|c|c|c|}
\hline Intervention 3 & \multicolumn{3}{|c|}{ Mean rank } & $x^{2}$ & $\mathrm{df}$ & $p$ \\
\hline$n=25$ & Pre- & $\begin{array}{l}\text { Post- } \\
\text { training }\end{array}$ & $\begin{array}{l}\text { Post- } \\
\text { exam }\end{array}$ & & & \\
\hline Knowledge & 1.04 & 2.14 & 2.82 & 41.163 & 2 & $<.0001$ \\
\hline Competence & 1.08 & 2.04 & 2.88 & 41.814 & 2 & $<.0001$ \\
\hline Comfort & 1.10 & 2.12 & 2.78 & 36.182 & 2 & $<.0001$ \\
\hline $\begin{array}{l}\text { Confidence in } \\
\text { training others }\end{array}$ & 1.14 & 2.08 & 2.78 & 34.202 & 2 & $<.0001$ \\
\hline
\end{tabular}


Figure 1. Trends in pre-intervention knowledge, competence, comfort level, and confidence in training others among Interventions 1, 2, and 3, Jonckheere-Terpsta boxplots.

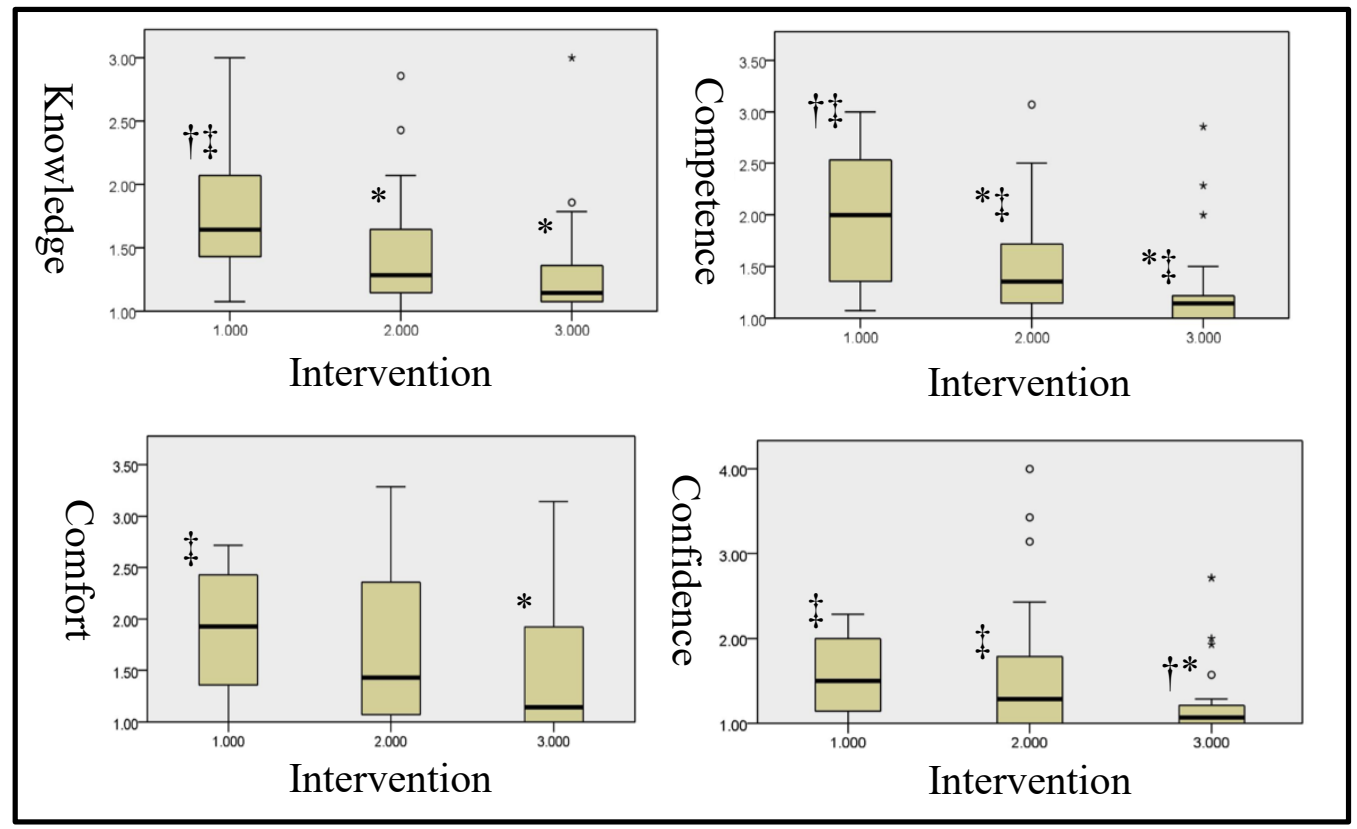

* Significantly different from 1

$\uparrow$ Significantly different from 2

†Significantly different from 3 
Figure 2. Trends in post-intervention knowledge, competence, comfort level, and confidence in training others among Interventions 1, 2, and 3, Jonckheere-Terpsta boxplots.

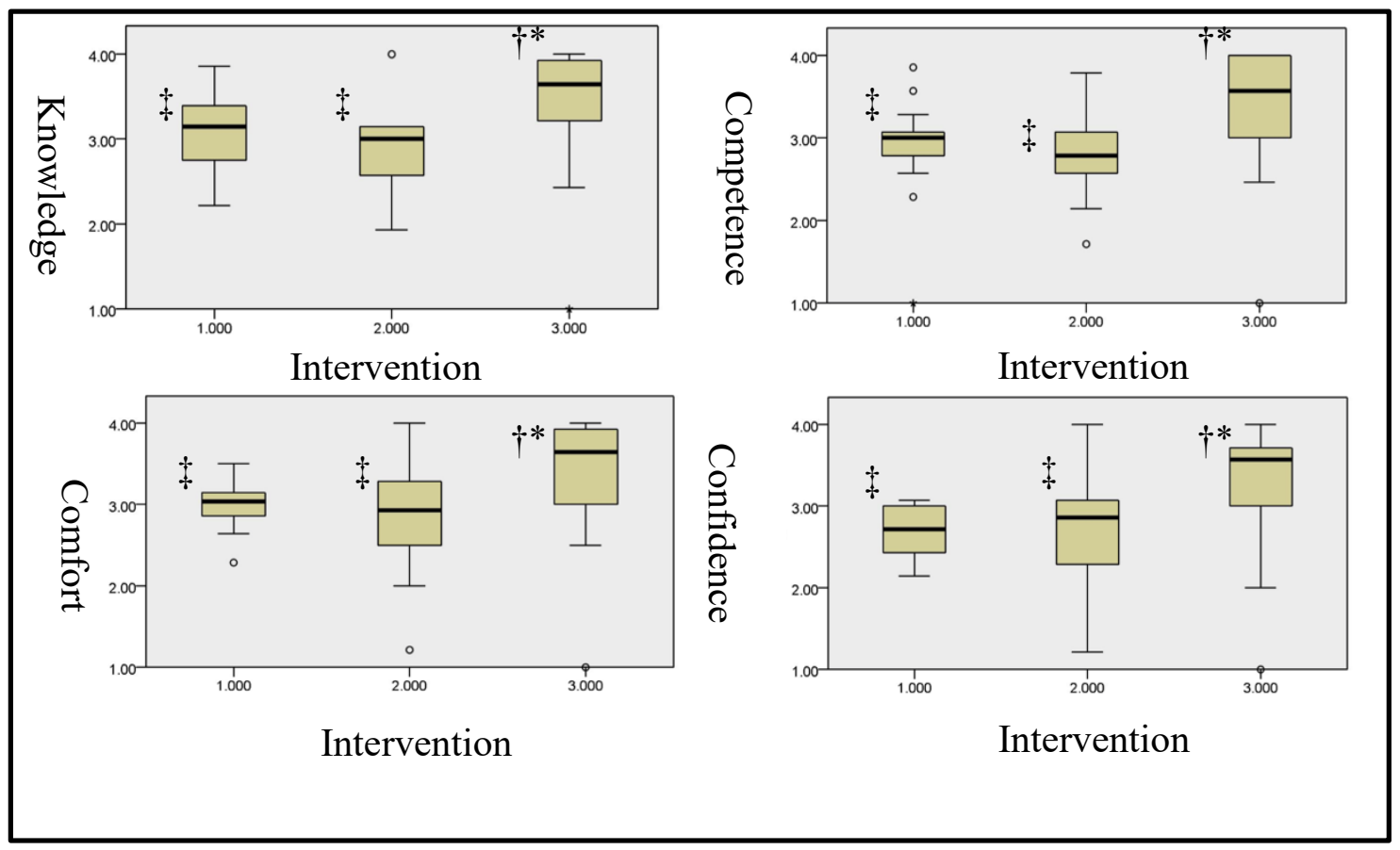

*Significantly different from 1

$\uparrow$ Significantly different from 2

†ignificantly different from 3 
Figure 3. Trends in pre- to post-intervention changes among Interventions 1, 2, and 3, Jonckheere-Terpsta boxplots.

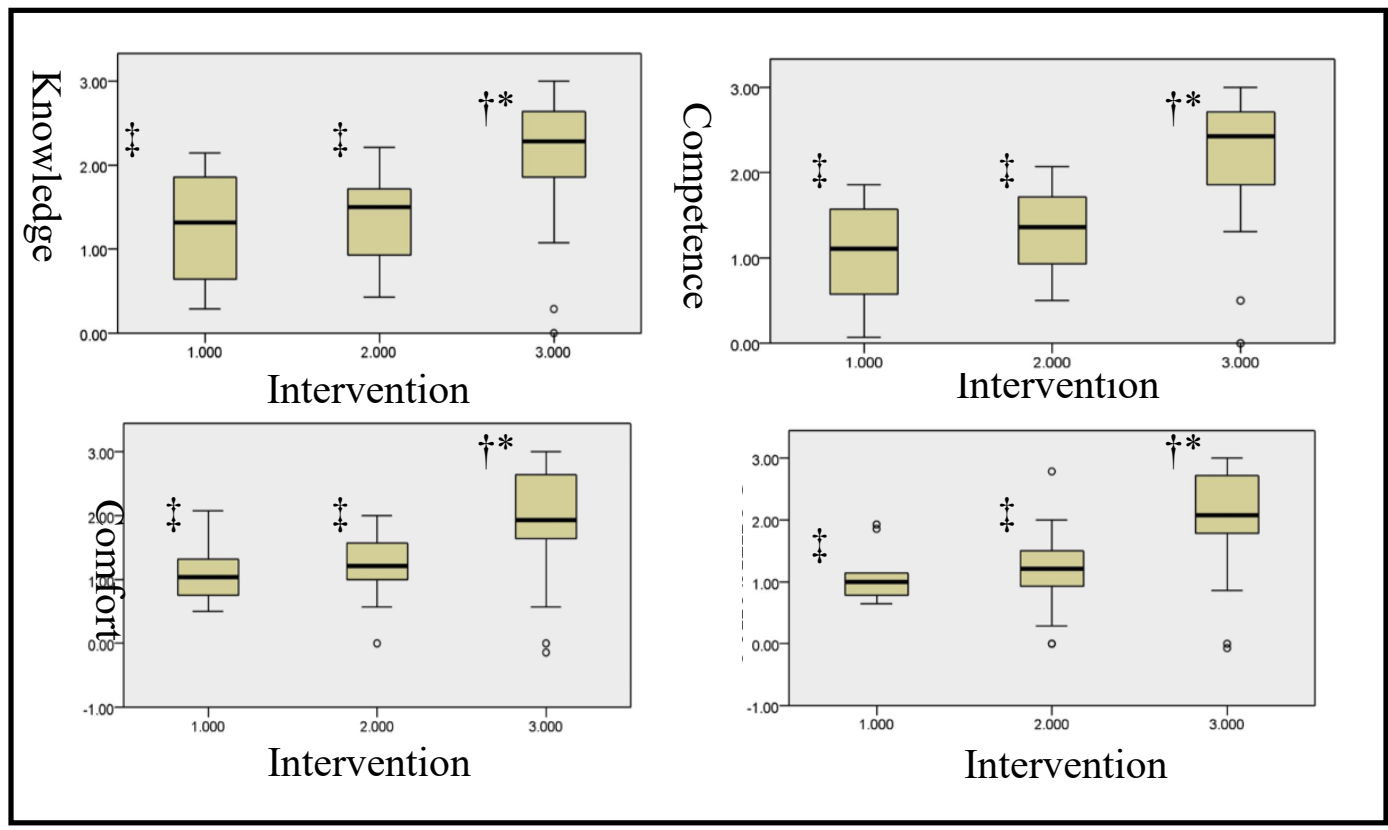

*Significantly different from 1

$\dagger$ Significantly different from 2

$\$$ Significantly different from 3 
Figure 4. Agreement between actual skill from the exam and self-reported competence (skill), Bland-Altman plot.

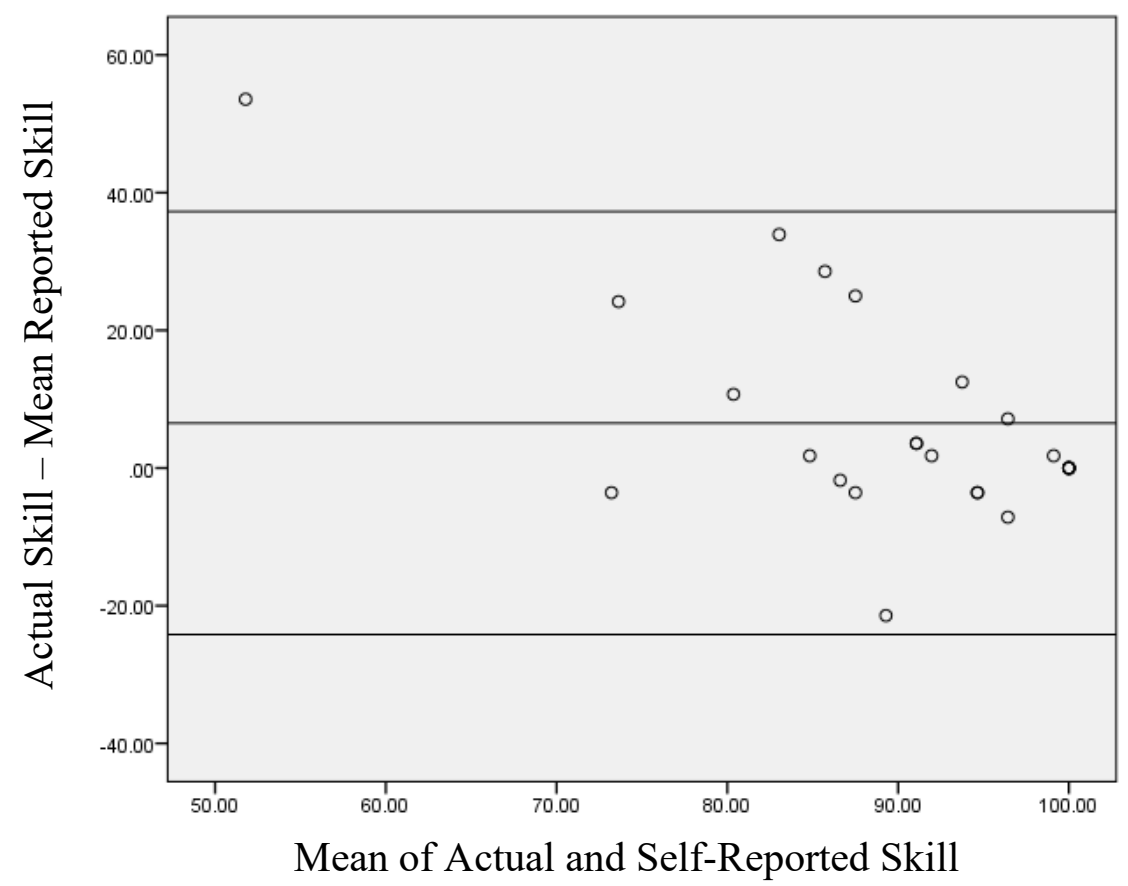

Intervention 1 - Retrospective Pre- and Post- Intervention Survey 
Please reflect on your knowledge, competence, and comfort level related to working with foodse prior to beginning FCS $384 / 387$, after completing FCs $384 / 387$, and after completing the Coordina (CPD).

In FCS $384 / 387$ you completed the following: equipment investigation project, etiquette dinner, $\mathrm{A}$ theme meal, and campus dining rotations.

This project has been certified as exempt by the University of Idaho Institutional Review Board. anonymous. Completion of the survey implies consent to participate and certifies you are at leas

Following completion, you will be redirected to a second survey. You will be asked to enter your receive a $\$ 5.00$ starbucks gift card for participation in this survey.

\begin{tabular}{|c|c|c|}
\hline ¿Alto-Sham Combination OvervSteamer & 口 Groen Steam Jacketec Ketle & DMenumaster High \\
\hline$\square$ Alto-Sham Cook Hoid Smoke Oven & DGroen Titing Braising Pan & DRobot Coupe Dice \\
\hline 口Amane Microwave & CHobart 20 Cuant Mover & DVuican Endurance \\
\hline [ Blodget Convection Oven ZephaireE & QHebart 60 Quart Morer & DVuican Salamande \\
\hline$\square$ Globe Slicer & DHobart Dishwasher AMn1s & \\
\hline
\end{tabular}

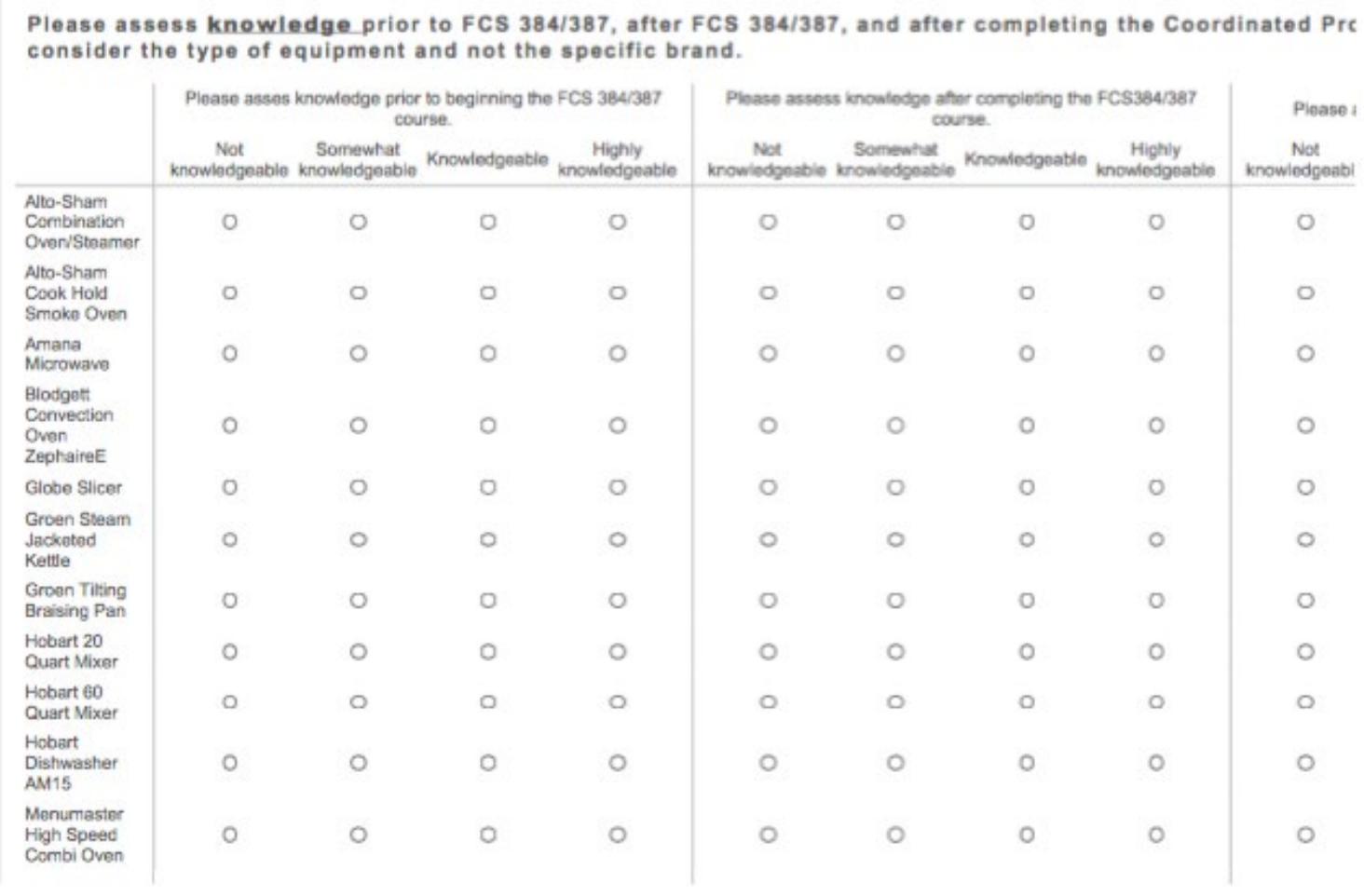




\begin{tabular}{|c|c|c|c|c|c|c|c|c|c|}
\hline & \multicolumn{4}{|c|}{$\begin{array}{c}\text { Please asses knowtedge pricr to begiming the FCS } 384 / 387 \\
\text { course. }\end{array}$} & \multicolumn{4}{|c|}{$\begin{array}{l}\text { Please assess knowledge afher completing the FCS364/387 } \\
\text { course. }\end{array}$} & \multirow{2}{*}{$\begin{array}{l}\text { Please } \\
\text { Not } \\
\text { knowledgeabi }\end{array}$} \\
\hline & $\begin{array}{l}\text { Not } \\
\text { knowledgeable }\end{array}$ & $\begin{array}{l}\text { Somewhat } \\
\text { knowledgeable }\end{array}$ & Knowledgeatle & $\begin{array}{c}\text { Highly } \\
\text { knowledgeatie }\end{array}$ & Nontedgeable & $\begin{array}{l}\text { Somowhat } \\
\text { knowledgeable }\end{array}$ & Knowledgeable & $\begin{array}{l}\text { Highly } \\
\text { knowledgeable }\end{array}$ & \\
\hline $\begin{array}{l}\text { Robot Coupe } \\
\text { Dice }\end{array}$ & 0 & 0 & 0 & 0 & 0 & 0 & 0 & 0 & 0 \\
\hline $\begin{array}{l}\text { Vulcan } \\
\text { Endurance / } \\
\text { Wolf } \\
\text { Challenger } \\
\text { Range }\end{array}$ & 0 & 0 & 0 & 0 & 0 & 0 & 0 & 0 & 0 \\
\hline $\begin{array}{l}\text { Vulcan } \\
\text { Salamander }\end{array}$ & 0 & 0 & 0 & 0 & 0 & 0 & 0 & 0 & 0 \\
\hline
\end{tabular}

Please assess competence (skill level) prior to FCS $384 / 387$, after FCS $384 / 387$, and after completing the ( (CPD). Please consider the type of equipment and not the specific brand.

\begin{tabular}{|c|c|c|c|c|c|c|c|c|c|c|c|c|}
\hline \multirow{3}{*}{$\begin{array}{l}\text { Nto-Sham } \\
\text { Combination } \\
\text { OverSteamer }\end{array}$} & \multicolumn{4}{|c|}{$\begin{array}{l}\text { Please asses competence prior bo begining } \\
\text { the FCS } 384 / 387 \text { courne. }\end{array}$} & \multicolumn{4}{|c|}{$\begin{array}{l}\text { Please assess comperience aher completing } \\
\text { the FCS } 334387 \text { counse. }\end{array}$} & \multicolumn{4}{|c|}{$\begin{array}{l}\text { Please assess competenoe aher completing } \\
\text { the CPD. }\end{array}$} \\
\hline & \multirow{2}{*}{$\begin{array}{c}\begin{array}{c}\text { Not } \\
\text { Compotont }\end{array} \\
0\end{array}$} & $\begin{array}{l}\text { Somewhat } \\
\text { Compeient }\end{array}$ & Competent & $\begin{array}{l}\text { Highy } \\
\text { Competent }\end{array}$ & \multirow{2}{*}{$\begin{array}{c}\begin{array}{c}\text { Not } \\
\text { Competent }\end{array} \\
0\end{array}$} & \multicolumn{2}{|c|}{$\begin{array}{l}\text { Somewhat Compesen } \\
\text { Competent }\end{array}$} & $\begin{array}{l}\text { Hophy } \\
\text { Competent }\end{array}$ & \multirow{2}{*}{$\begin{array}{c}\text { Not } \\
\text { Competent } \\
0\end{array}$} & \multirow{2}{*}{$\begin{array}{c}\text { Somenhat } \\
\text { Competent } \\
0 \\
0\end{array}$} & \multirow{2}{*}{$\begin{array}{c}\text { Competent } \\
0\end{array}$} & \multirow{2}{*}{$\begin{array}{c}\begin{array}{c}\text { Highly } \\
\text { Competer }\end{array} \\
0\end{array}$} \\
\hline & & o & 0 & 0 & & 0 & 0 & 0 & & & & \\
\hline $\begin{array}{l}\text { Alto-Sham } \\
\text { Cook Hokd } \\
\text { Smoke Oven }\end{array}$ & 0 & 0 & 0 & 0 & 0 & 0 & 0 & 0 & 0 & 0 & 0 & 0 \\
\hline $\begin{array}{l}\text { Amana } \\
\text { Mlerowave }\end{array}$ & $\circ$ & 0 & o & ○ & ० & 0 & ○ & o & $\circ$ & 0 & ○ & ० \\
\hline $\begin{array}{l}\text { Blodget: } \\
\text { Convection } \\
\text { Oven } \\
\text { ZeptaireE }\end{array}$ & 0 & 0 & 0 & 0 & 0 & 0 & 0 & 0 & 0 & 0 & o & 0 \\
\hline Globe Slicer & o & 0 & 0 & 0 & 0 & 0 & 0 & 0 & 0 & 0 & 0 & 0 \\
\hline $\begin{array}{l}\text { Groen Steam } \\
\text { Jackoted } \\
\text { Kettle }\end{array}$ & 0 & 0 & 0 & 0 & 0 & 0 & 0 & 0 & 0 & 0 & 0 & 0 \\
\hline $\begin{array}{l}\text { Groen Tiling } \\
\text { Braising Pan }\end{array}$ & 0 & 0 & 0 & 0 & 0 & 0 & 0 & 0 & 0 & 0 & 0 & 0 \\
\hline $\begin{array}{l}\text { Hebart } 20 \\
\text { Quart Mixer }\end{array}$ & 0 & 0 & 0 & 0 & 0 & 0 & 0 & 0 & 0 & 0 & 0 & 0 \\
\hline $\begin{array}{l}\text { Hobart } 60 \\
\text { Quart Mixer }\end{array}$ & 0 & 0 & 0 & 0 & 0 & 0 & 0 & 0 & 0 & 0 & 0 & 0 \\
\hline $\begin{array}{l}\text { Hobart } \\
\text { Dishwasher } \\
\text { AM15 }\end{array}$ & 0 & 0 & 0 & 0 & 0 & 0 & 0 & 0 & 0 & 0 & 0 & 0 \\
\hline $\begin{array}{l}\text { Menumaster } \\
\text { High Speed } \\
\text { Combi Oven }\end{array}$ & 0 & 0 & 0 & 0 & 0 & 0 & 0 & 0 & 0 & 0 & 0 & 0 \\
\hline $\begin{array}{l}\text { Robot Coupe } \\
\text { Dice }\end{array}$ & 0 & 0 & 0 & 0 & 0 & 0 & o & 0 & 0 & 0 & 0 & 0 \\
\hline $\begin{array}{l}\text { Vulcan } \\
\text { Encurance / } \\
\text { Wolf } \\
\text { Challenger } \\
\text { Range }\end{array}$ & 0 & 0 & 0 & 0 & 0 & 0 & 0 & 0 & 0 & 0 & 0 & 0 \\
\hline $\begin{array}{l}\text { Vulcan } \\
\text { Salamender }\end{array}$ & 0 & 0 & 0 & 0 & 0 & 0 & 0 & 0 & 0 & 0 & 0 & 0 \\
\hline
\end{tabular}

Please assess comfort level in using the equipment prior to FCS $384 / 387$, after FCS $384 / 387$, and after comf in Dietetics (CPD). Please consider the type of equipment and not the specific brand.

\begin{tabular}{|c|c|c|c|c|c|c|c|c|c|c|c|}
\hline & \multicolumn{4}{|c|}{$\begin{array}{l}\text { Please asses comfort level prior to beginning the } \\
\text { FCS } 384 / 387 \text { course. }\end{array}$} & \multicolumn{4}{|c|}{$\begin{array}{l}\text { Please assess comfort leval ater comploting the } \\
\text { FCS } 364 / 347 \text { course. }\end{array}$} & \multicolumn{3}{|c|}{$\begin{array}{l}\text { Please assess comfort lovel after } C \\
\text { CPD. }\end{array}$} \\
\hline & $\begin{array}{l}\text { Not } \\
\text { Comfortabie }\end{array}$ & $\begin{array}{l}\text { Somewhat } \\
\text { Comfortable }\end{array}$ & Comfortable & $\begin{array}{l}\text { Highly } \\
\text { Comfortable }\end{array}$ & $\begin{array}{l}\text { Not } \\
\text { Comfortabie }\end{array}$ & $\begin{array}{l}\text { Somewhat } \\
\text { Comfortable }\end{array}$ & Comfortablo & $\begin{array}{l}\text { Highly } \\
\text { Comfortabie }\end{array}$ & $\begin{array}{l}\text { Not } \\
\text { Comfortable }\end{array}$ & $\begin{array}{l}\text { Somemhat } \\
\text { Comfortable }\end{array}$ & Comfortal \\
\hline \multirow{2}{*}{$\begin{array}{l}\text { Alto-Sham } \\
\text { Combination } \\
\text { Over/Steamer }\end{array}$} & 0 & 0 & 0 & 0 & 0 & 0 & 0 & 0 & 0 & 0 & 0 \\
\hline & 0 & 0 & 0 & 0 & 0 & 0 & 0 & 0 & 0 & 0 & 0 \\
\hline
\end{tabular}




\begin{tabular}{|c|c|c|c|c|c|c|c|c|c|c|c|}
\hline & \multicolumn{4}{|c|}{$\begin{array}{l}\text { Please asses comfont level prior to beginning the } \\
\text { FCS } 384 / 387 \text { course. }\end{array}$} & \multicolumn{4}{|c|}{$\begin{array}{l}\text { Piease assess comfort ievel ater completing the } \\
\text { FCS 304/387 course. }\end{array}$} & \multicolumn{3}{|c|}{$\begin{array}{l}\text { Please assess comfon level after } c \\
\qquad C P D\end{array}$} \\
\hline & $\begin{array}{c}\text { Not } \\
\text { Comforiabie }\end{array}$ & $\begin{array}{l}\text { Somewhat } \\
\text { Comfortable }\end{array}$ & Comforable & $\begin{array}{c}\text { Highly } \\
\text { Comforiabie }\end{array}$ & $\begin{array}{l}\text { Not } \\
\text { Comfortable }\end{array}$ & $\begin{array}{l}\text { Somenthat } \\
\text { Comlontable }\end{array}$ & Comfortable & $\begin{array}{l}\text { Highly } \\
\text { Comfortabie }\end{array}$ & $\begin{array}{l}\text { Not } \\
\text { Comflortable }\end{array}$ & $\begin{array}{l}\text { Somewhat } \\
\text { Comfortatie }\end{array}$ & Comfortal \\
\hline \multicolumn{12}{|l|}{$\begin{array}{l}\text { Alto-Sham } \\
\text { Cook Hold } \\
\text { Smoke Oven }\end{array}$} \\
\hline $\begin{array}{l}\text { Amana } \\
\text { Microwave }\end{array}$ & O & 0 & 0 & 0 & $\circ$ & 0 & 0 & 0 & $\circ$ & 0 & 0 \\
\hline $\begin{array}{l}\text { Blodget: } \\
\text { Convection } \\
\text { Oven } \\
\text { ZephaireE }\end{array}$ & 0 & 0 & 0 & 0 & 0 & 0 & 0 & 0 & 0 & 0 & 0 \\
\hline Globe Slicer & 0 & 0 & 0 & 0 & o & 0 & 0 & 0 & 0 & 0 & 0 \\
\hline $\begin{array}{l}\text { Groon Ssoam } \\
\text { Jackoted } \\
\text { Kettle }\end{array}$ & 0 & 0 & $\circ$ & 0 & $\circ$ & 0 & 0 & 0 & $\circ$ & 0 & 0 \\
\hline $\begin{array}{l}\text { Groen Tiling } \\
\text { Braising Pan }\end{array}$ & 0 & $\circ$ & 0 & 0 & $\circ$ & $\circ$ & 0 & 0 & 0 & $\circ$ & 0 \\
\hline $\begin{array}{l}\text { Hobart } 20 \\
\text { Quart Mixer }\end{array}$ & ० & $\circ$ & $\circ$ & 0 & 0 & 0 & 0 & 0 & 0 & 0 & 0 \\
\hline $\begin{array}{l}\text { Hobart } 60 \\
\text { Quart Mixer }\end{array}$ & 0 & 0 & $\circ$ & $\circ$ & $\circ$ & $\circ$ & 0 & 0 & $\circ$ & $\circ$ & 0 \\
\hline $\begin{array}{l}\text { Hobart } \\
\text { Dishwashor } \\
\text { AM15 }\end{array}$ & 0 & 0 & 0 & 0 & 0 & 0 & 0 & 0 & 0 & 0 & 0 \\
\hline $\begin{array}{l}\text { Menumaster } \\
\text { High Speed } \\
\text { Combi Oven }\end{array}$ & 0 & 0 & 0 & 0 & 0 & 0 & 0 & 0 & 0 & 0 & 0 \\
\hline $\begin{array}{l}\text { Robot Coupo } \\
\text { Dice }\end{array}$ & $\circ$ & $\circ$ & $\circ$ & 0 & $\circ$ & $\circ$ & 0 & o & $\circ$ & 0 & 0 \\
\hline $\begin{array}{l}\text { Vuican } \\
\text { Enturance / } \\
\text { Woif } \\
\text { Challanger } \\
\text { Range }\end{array}$ & 0 & 0 & 0 & 0 & 0 & 0 & 0 & 0 & 0 & 0 & 0 \\
\hline $\begin{array}{l}\text { Vulcan } \\
\text { Salamender }\end{array}$ & 0 & 0 & 0 & 0 & 0 & 0 & 0 & 0 & ○ & 0 & 0 \\
\hline
\end{tabular}

Please assess confidence level in being able to train someone on the equipment prior to FCS 384/387, afte completing the Coordinated Program in Dietetics (CPD). Please consider the type of equipment and not the $s$

\begin{tabular}{|c|c|c|c|c|c|c|c|c|c|c|c|c|}
\hline & \multicolumn{4}{|c|}{$\begin{array}{l}\text { Please asses confident levei prior to } \\
\text { beginning the FCS } 384 / 387 \text { course. }\end{array}$} & \multicolumn{4}{|c|}{$\begin{array}{l}\text { Please assess confident level ator } \\
\text { completing the FCS } 384387 \text { course. }\end{array}$} & \multicolumn{4}{|c|}{$\begin{array}{l}\text { Please assoss confident level atter } \\
\text { completing the CPD. }\end{array}$} \\
\hline & $\begin{array}{c}\text { Not } \\
\text { Confident }\end{array}$ & $\begin{array}{l}\text { Somewhat } \\
\text { Confident }\end{array}$ & Contident & $\begin{array}{l}\text { Highly } \\
\text { Conficent }\end{array}$ & $\begin{array}{l}\text { Not } \\
\text { Confident }\end{array}$ & $\begin{array}{l}\text { Somewhat } \\
\text { Confident }\end{array}$ & Confident & $\begin{array}{l}\text { Highly } \\
\text { Confident }\end{array}$ & $\begin{array}{l}\text { Not } \\
\text { Confident }\end{array}$ & $\begin{array}{l}\text { Somowhat } \\
\text { Confident }\end{array}$ & Confident & $\begin{array}{l}\text { Highly } \\
\text { Confident }\end{array}$ \\
\hline $\begin{array}{l}\text { Alto-Sham } \\
\text { Combination } \\
\text { Over/Steamer }\end{array}$ & 0 & 0 & 0 & 0 & 0 & 0 & 0 & 0 & 0 & 0 & 0 & 0 \\
\hline $\begin{array}{l}\text { Alto-Sham } \\
\text { Cook Hold } \\
\text { Smoke Oven }\end{array}$ & 0 & 0 & 0 & 0 & 0 & 0 & 0 & 0 & 0 & 0 & 0 & 0 \\
\hline $\begin{array}{l}\text { Amana } \\
\text { Microwave }\end{array}$ & 0 & 0 & 0 & 0 & 0 & 0 & 0 & 0 & 0 & 0 & 0 & 0 \\
\hline $\begin{array}{l}\text { Blodgott } \\
\text { Convection } \\
\text { Oven } \\
\text { ZephaireE }\end{array}$ & 0 & 0 & 0 & 0 & 0 & 0 & 0 & 0 & 0 & 0 & 0 & 0 \\
\hline Globe Slicer & 0 & 0 & 0 & 0 & 0 & 0 & 0 & 0 & 0 & 0 & 0 & 0 \\
\hline $\begin{array}{l}\text { Groen Steam } \\
\text { Jacketed } \\
\text { Kottle }\end{array}$ & 0 & 0 & 0 & 0 & 0 & 0 & 0 & 0 & 0 & 0 & 0 & 0 \\
\hline $\begin{array}{l}\text { Groen Titing } \\
\text { Braising Pan }\end{array}$ & 0 & 0 & 0 & 0 & 0 & 0 & 0 & 0 & 0 & 0 & 0 & 0 \\
\hline $\begin{array}{l}\text { Hebart } 20 \\
\text { Quart Mixer }\end{array}$ & 0 & 0 & 0 & 0 & 0 & 0 & 0 & 0 & 0 & 0 & 0 & 0 \\
\hline $\begin{array}{l}\text { Hobart } 60 \\
\text { Quart Mixar }\end{array}$ & 0 & 0 & 0 & 0 & 0 & 0 & 0 & 0 & 0 & 0 & 0 & 0 \\
\hline \multirow[t]{2}{*}{$\begin{array}{l}\text { Hobart } \\
\text { Dishwasher } \\
\text { AM15 }\end{array}$} & 0 & 0 & 0 & 0 & 0 & 0 & 0 & 0 & 0 & 0 & 0 & 0 \\
\hline & 0 & 0 & 0 & 0 & 0 & 0 & 0 & 0 & 0 & 0 & 0 & 0 \\
\hline
\end{tabular}




\begin{tabular}{|c|c|c|c|c|c|c|c|c|c|c|c|c|}
\hline & \multicolumn{4}{|c|}{$\begin{array}{l}\text { Please asses conficent level prior to } \\
\text { beginning the FCS } 384 / 387 \text { course. }\end{array}$} & \multicolumn{4}{|c|}{$\begin{array}{l}\text { Please assess conficent level atter } \\
\text { completing the FCS } 384 / 367 \text { course. }\end{array}$} & \multicolumn{4}{|c|}{$\begin{array}{l}\text { Please assess confidert level after } \\
\text { completing the CPD. }\end{array}$} \\
\hline & $\begin{array}{l}\text { Not } \\
\text { Confident }\end{array}$ & $\begin{array}{l}\text { Somewhat } \\
\text { Confident }\end{array}$ & Confident & $\begin{array}{l}\text { Highly } \\
\text { Conficent }\end{array}$ & $\begin{array}{l}\text { Not } \\
\text { Confident }\end{array}$ & $\begin{array}{l}\text { Somowhat } \\
\text { Confident }\end{array}$ & Corfident & $\begin{array}{l}\text { Highly } \\
\text { Confident }\end{array}$ & $\begin{array}{l}\text { Not } \\
\text { Confident }\end{array}$ & $\begin{array}{l}\text { Sornowhat } \\
\text { Confident }\end{array}$ & Confident & $\begin{array}{l}\text { Highly } \\
\text { Confident }\end{array}$ \\
\hline \multicolumn{13}{|l|}{$\begin{array}{l}\text { Menumaster } \\
\text { High Speod } \\
\text { Combi Oven }\end{array}$} \\
\hline $\begin{array}{l}\text { Robot Coupe } \\
\text { Dice }\end{array}$ & 0 & 0 & 0 & 0 & 0 & o & 0 & 0 & 0 & 0 & 0 & 0 \\
\hline $\begin{array}{l}\text { Vulcan } \\
\text { Endurance/ } \\
\text { Wolf } \\
\text { Challenger } \\
\text { Range }\end{array}$ & 0 & 0 & 0 & 0 & 0 & 0 & 0 & 0 & 0 & 0 & 0 & 0 \\
\hline $\begin{array}{l}\text { Vuican } \\
\text { Salamander }\end{array}$ & 0 & 0 & 0 & 0 & 0 & 0 & 0 & 0 & 0 & o & 0 & 0 \\
\hline
\end{tabular}

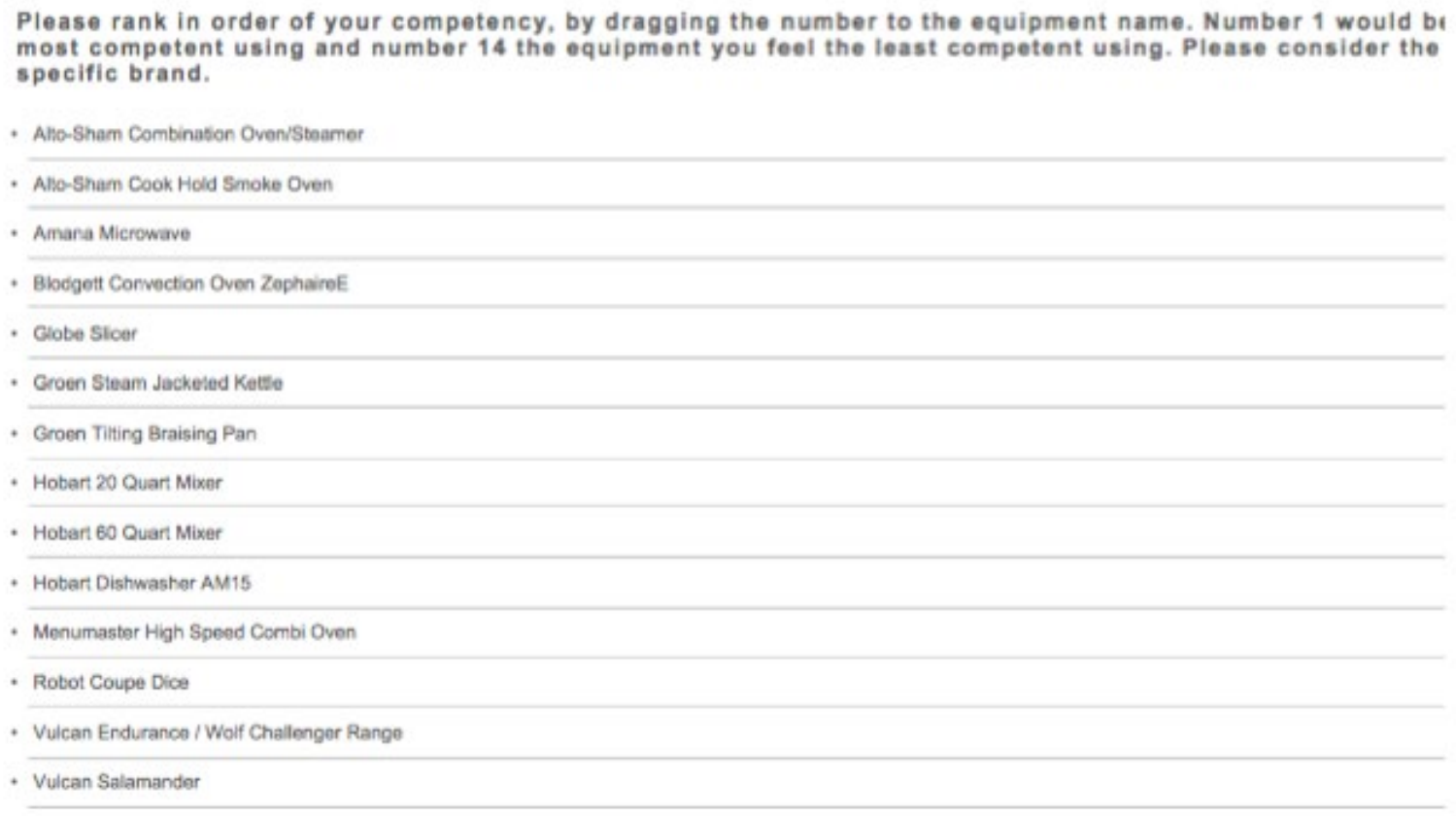

Please describe areas of foodservice equipment use in which you do not feel knowledgeable, confident, or c

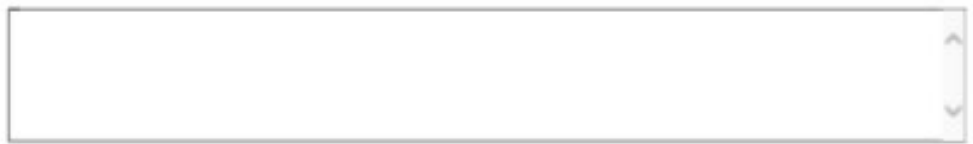

Please describe foodservice experiences and resources prior to the FCS $384 / 387$ course that contributed to and comfort level using foodservice equipment. 
Please describe foodservice experiences and resources during your CPD senior year that contributed to you comfort level using foodservice equipment.

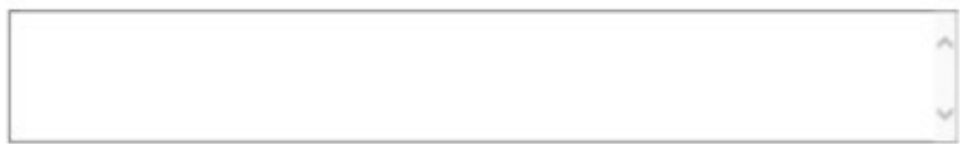

Please describe recommendations for equipment training for FCS 384/387 students.

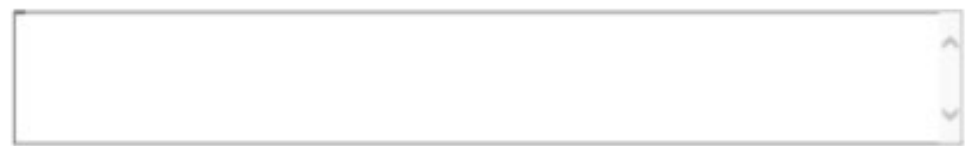

Thank you for participating in this project.

Following completion, you will be redirected to a second survey. You will be asked to enter your receive a $\$ 5.00$ starbucks gift card for participation in this survey.

All survey responses are anonymous. Your name will not be linked to the previous responses. 
Intervention 2 - Retrospective Pre- and Post- Intervention Survey

Default Question Block

Please reflect on your knowledge, competence, and comfort level related to working with foodservice equipment both currently and prior to beginning FCs 384.

This project has been certified as exempt by the University of Idaho Institutional Review Board. All responses are anonymous. Completion of the survey implies consent to participate and certifies you are at least 18 years of age.

Following the survey, you will be redirected to a second survey to enter your name and receive class credit for completing the activity.

Prier to FCS 384 piease eheck all the equipment that you have used before. If you have used the type of equipment before but from a different company (different brand), you can still check the box.

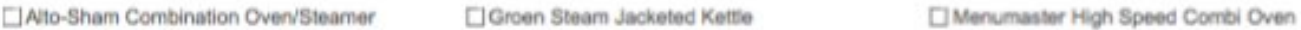

Dilo-Sham Cook Hold Smoke Over

CGroen Titing Braising Pan

DRobot Coupe Dice

בAmana Miorowave

CHobart 20 Quart Mixer

DVucan Enourance / Wolt Chatenger Range

DBodgett Comection Oven ZephaireE

CHobat 60 Quart Mixer

DVukan Salamander

口Clobe Slicer

CHobart Dishwasher AM15

Please assess knowledge prior to FCS 384 and after the competency exam. Please consider the type of equipment and not the specific brand.

\begin{tabular}{|c|c|} 
Please asses knowledge prior to beginning the FCS 394 course. & $\begin{array}{c}\text { Not } \\
\text { Somewhat } \\
\text { knowledgeable knowledgeable }\end{array}$
\end{tabular} Knowledgeable $\begin{gathered}\text { Highly } \\
\text { knowledgeable }\end{gathered} \mid$

Please assess knowledge afler completing the equipment competency exam. Not Somewhat Knowledgeable
knowledighly
knowieable

Combination
Oven/Steamer

Alto-Sham

Cook Hold

Smoke Oven

Amana

Microwave

Blodgett

Convection

Oven

ZephaireE

Globe Slicer

Groen Steam

Jacketed

Jackete

Groen Tilting

Braising Pan

Hobart 20

Quart Mixer

Hobart 60

Quart Mixer

Hobart

Dishwasher

AM15

Menumaster

High Speed

Combi Oven

Nedgeable knowledgeable Knowledgeazle knowledgeable

$0 \quad 0 \quad 0$

$0 \quad 0 \quad 0$

O

O

O

O$$
0
$$

o

O

0

0

0

0

O

o

0

$0 \quad 0$

o 0

○

0 


\begin{tabular}{|c|c|c|c|c|c|c|c|c|}
\hline & \multicolumn{4}{|c|}{ Please asses knowledge prior to beginning the FCS 384 course. } & \multicolumn{4}{|c|}{$\begin{array}{l}\text { Please assess knowledge afher completing the equipment } \\
\text { competency exam. }\end{array}$} \\
\hline & $\begin{array}{c}\text { Not } \\
\text { knowlecgeable }\end{array}$ & $\begin{array}{l}\text { Somewhat } \\
\text { knowledgeable }\end{array}$ & Knowledgeable & $\begin{array}{c}\text { Highly } \\
\text { knowledgeable }\end{array}$ & $\begin{array}{l}\text { Not } \\
\text { knowledgeable }\end{array}$ & $\begin{array}{l}\text { Somewhat } \\
\text { knowledgeable }\end{array}$ & Knowledgeable & $\begin{array}{l}\text { Highly } \\
\text { knowledgeable }\end{array}$ \\
\hline \multicolumn{9}{|l|}{$\begin{array}{l}\text { Robot Coupe } \\
\text { Dice }\end{array}$} \\
\hline $\begin{array}{l}\text { Vulcan } \\
\text { Endurance / } \\
\text { Wolf } \\
\text { Challenger } \\
\text { Range }\end{array}$ & 0 & O & 0 & 0 & 0 & 0 & 0 & 0 \\
\hline $\begin{array}{l}\text { Vulcan } \\
\text { Salamander }\end{array}$ & 0 & 0 & 0 & 0 & 0 & 0 & 0 & 0 \\
\hline
\end{tabular}

Please assess competence (skill level) prior to FCS 384 and after the competency exam. Please consider the type of equipment and not the specific brand.

\begin{tabular}{c|c|} 
Please asses competence prior to beginning \\
the FCS 384 oourse. \\
$\begin{array}{c}\text { Not Somewhat } \\
\text { Competent Competent Competent Competent }\end{array}$
\end{tabular}

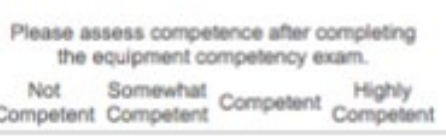

$\begin{array}{lllllll}0 & 0 & 0 & 0 & 0 & 0 & 0\end{array}$

$\begin{array}{lllllll}0 & 0 & 0 & 0 & 0 & 0 & 0\end{array}$

$\begin{array}{llllllll}0 & 0 & 0 & 0 & 0 & 0 & 0 & 0 \\ 0 & 0 & 0 & 0 & 0 & 0 & 0 & 0\end{array}$

$\begin{array}{lllllll}0 & 0 & 0 & 0 & 0 & 0 & 0 \\ 0 & 0 & 0 & 0 & 0\end{array}$

$\begin{array}{lllllll}0 & 0 & 0 & 0 & 0 & 0 & 0\end{array}$

$\begin{array}{lllllll}0 & 0 & 0 & 0 & 0 & 0 & 0\end{array}$

$\begin{array}{lllllll}0 & 0 & 0 & 0 & 0 & 0 & 0\end{array}$

$\begin{array}{lllllll}0 & 0 & 0 & 0 & 0 & 0 & 0\end{array}$

0000

$\begin{array}{llllllllll}0 & 0 & 0 & 0\end{array}$

0 o 0 o 0

$\begin{array}{lllll}0 & 0 & 0 & 0 & 0\end{array}$

$\begin{array}{lllllll}0 & 0 & 0 & 0 & 0 & 0 & 0\end{array}$

$\begin{array}{llllllll}0 & 0 & 0 & 0 & 0 & 0 & 0 & 0 \\ 0 & 0 & 0 & 0 & 0 & 0 & 0 & 0 \\ 0 & 0 & 0 & 0 & 0 & 0 & 0 & 0\end{array}$

Please assess comfort level in using the equipment prior to FCS 384 and after the competency exam. Please consider the type of equipment and not the specific brand.

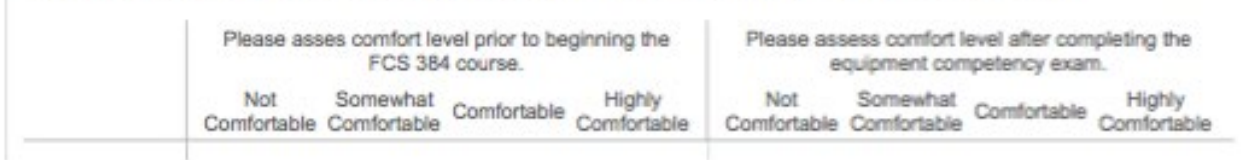




\begin{tabular}{|c|c|c|c|c|c|c|c|c|}
\hline & \multicolumn{4}{|c|}{$\begin{array}{l}\text { Please asses comfort level prior to beginning the } \\
\text { FCS } 384 \text { course. }\end{array}$} & \multicolumn{4}{|c|}{$\begin{array}{l}\text { Please assess confort level after completing the } \\
\text { equipment competency exam. }\end{array}$} \\
\hline & $\begin{array}{l}\text { Not } \\
\text { Comfortable }\end{array}$ & $\begin{array}{l}\text { Somewhat } \\
\text { Comfortable }\end{array}$ & Comfortable & $\begin{array}{l}\text { Highly } \\
\text { Comfortable }\end{array}$ & $\begin{array}{l}\text { Not } \\
\text { Comfortable }\end{array}$ & $\begin{array}{l}\text { Somewhat } \\
\text { Comfortabie }\end{array}$ & Contontable & $\begin{array}{l}\text { Highly } \\
\text { Comfortable }\end{array}$ \\
\hline $\begin{array}{l}\text { Alto-Sham } \\
\text { Combination } \\
\text { Oven/Steamer }\end{array}$ & 0 & 0 & 0 & 0 & 0 & 0 & 0 & 0 \\
\hline $\begin{array}{l}\text { Alto-Sham } \\
\text { Cook Hold } \\
\text { Smoke Oven }\end{array}$ & 0 & 0 & 0 & 0 & 0 & 0 & 0 & 0 \\
\hline $\begin{array}{l}\text { Amana } \\
\text { Microwave }\end{array}$ & 0 & 0 & 0 & 0 & 0 & 0 & 0 & 0 \\
\hline $\begin{array}{l}\text { Blodgett } \\
\text { Convection } \\
\text { Oven } \\
\text { ZephaireE }\end{array}$ & 0 & 0 & 0 & 0 & 0 & 0 & 0 & 0 \\
\hline Globe Sticer & 0 & 0 & 0 & 0 & 0 & 0 & 0 & 0 \\
\hline $\begin{array}{l}\text { Groen Steam } \\
\text { Jacketed } \\
\text { Kettle }\end{array}$ & 0 & 0 & 0 & 0 & 0 & 0 & 0 & 0 \\
\hline $\begin{array}{l}\text { Groen Tilting } \\
\text { Braising Pan }\end{array}$ & 0 & 0 & 0 & 0 & 0 & 0 & 0 & 0 \\
\hline $\begin{array}{l}\text { Hobart } 20 \\
\text { Quart Mixer }\end{array}$ & 0 & 0 & 0 & 0 & 0 & 0 & 0 & 0 \\
\hline $\begin{array}{l}\text { Hobart } 60 \\
\text { Quart Mixer }\end{array}$ & 0 & 0 & 0 & 0 & 0 & 0 & 0 & 0 \\
\hline $\begin{array}{l}\text { Hobart } \\
\text { Dishwasher } \\
\text { AM15 }\end{array}$ & 0 & 0 & 0 & 0 & 0 & 0 & 0 & 0 \\
\hline $\begin{array}{l}\text { Merumaster } \\
\text { High Speed } \\
\text { Combi Oven }\end{array}$ & 0 & 0 & 0 & 0 & O & 0 & 0 & 0 \\
\hline $\begin{array}{l}\text { Robot Coupe } \\
\text { Dice }\end{array}$ & 0 & 0 & 0 & 0 & 0 & 0 & 0 & 0 \\
\hline $\begin{array}{l}\text { Vulcan } \\
\text { Endurance / } \\
\text { Wolf } \\
\text { Challenger } \\
\text { Range }\end{array}$ & 0 & 0 & 0 & 0 & 0 & 0 & 0 & 0 \\
\hline $\begin{array}{l}\text { Vulcan } \\
\text { Salamander }\end{array}$ & 0 & 0 & 0 & 0 & 0 & 0 & 0 & 0 \\
\hline
\end{tabular}

Please assess confidence level in being able to train someone on the equipment prior to FCS 384 and after the competency exam. Please consider the type of equipment and not the specific brand.

\begin{tabular}{|c|c|c|c|c|c|c|c|c|}
\hline & \multicolumn{4}{|c|}{$\begin{array}{l}\text { Please asses confident level prior to } \\
\text { beginning the FCS } 384 \text { course. }\end{array}$} & \multicolumn{4}{|c|}{$\begin{array}{l}\text { Please assess confident level atter } \\
\text { completing the equipment competency } \\
\text { exam. }\end{array}$} \\
\hline & $\begin{array}{c}\text { Not } \\
\text { Confident }\end{array}$ & $\begin{array}{l}\text { Somewhat } \\
\text { Confident }\end{array}$ & Conficent & $\begin{array}{l}\text { Highly } \\
\text { Confident }\end{array}$ & $\begin{array}{c}\text { Not } \\
\text { Conficent }\end{array}$ & $\begin{array}{l}\text { Somewhat } \\
\text { Confident }\end{array}$ & Contident & $\begin{array}{l}\text { Highly } \\
\text { Conifient }\end{array}$ \\
\hline $\begin{array}{l}\text { Alto-Sham } \\
\text { Combination } \\
\text { Oven/Steamer }\end{array}$ & 0 & 0 & 0 & 0 & 0 & 0 & 0 & 0 \\
\hline $\begin{array}{l}\text { Alto-Sham } \\
\text { Cook Hold } \\
\text { Smoke Oven }\end{array}$ & 0 & 0 & 0 & 0 & 0 & 0 & 0 & 0 \\
\hline $\begin{array}{l}\text { Amana } \\
\text { Microwave }\end{array}$ & 0 & 0 & 0 & 0 & 0 & 0 & 0 & 0 \\
\hline $\begin{array}{l}\text { Blodgett } \\
\text { Convection } \\
\text { Oven } \\
\text { ZephaireE }\end{array}$ & 0 & 0 & 0 & 0 & 0 & 0 & 0 & 0 \\
\hline Globe Slicer & 0 & 0 & 0 & 0 & 0 & 0 & 0 & 0 \\
\hline $\begin{array}{l}\text { Groen Steam } \\
\text { Jacketed } \\
\text { Kettle }\end{array}$ & 0 & 0 & 0 & 0 & 0 & 0 & 0 & 0 \\
\hline $\begin{array}{l}\text { Groen Tilting } \\
\text { Braising Pan }\end{array}$ & 0 & 0 & 0 & 0 & 0 & 0 & 0 & 0 \\
\hline
\end{tabular}




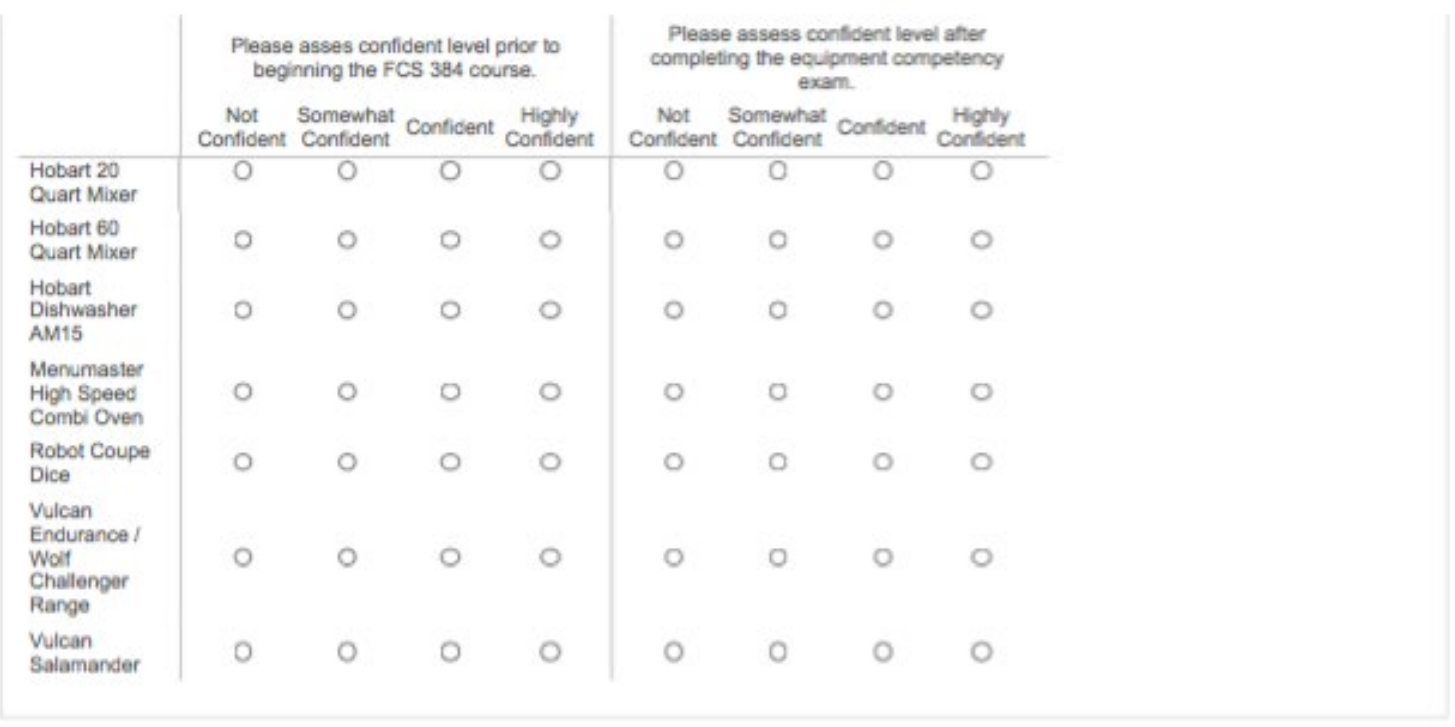

Please rank in order of your competency, by dragging the number to the equipment name. Number 1 would be the equipment you feel the most competent using and number 14 the equipment you feel the least competent using. Please consider the type of equipment and not the specific brand.

- Alto-Sham Combinaton Oven/Steamer

- Alto-Sham Cook Hold Smoke Oven

- Amana Microwave

- Blodgett Convection Oven ZephaireE

- Globe Slicer

- Groen Steam Jacketed Kettle

- Groen Titing Braising Pan

- Hobart 20 Quart Mixer

- Hobart 60 Quart Mixer

- Hobart Distwasher AM15

- Menumaster High Speed Combi Oven

- Robot Coupe Dice

- Vulcan Endurance / Woit Challenger Range

- Vulcan Salamander

Please describe areas of foodservice equipment use in which you do not feel knowledgeable, confident, or comfortable. 
Please describe food service experiences and resources prior to the FCS 384 course that contributed to your knowledge, competence and comfort level using foodservice equipment.

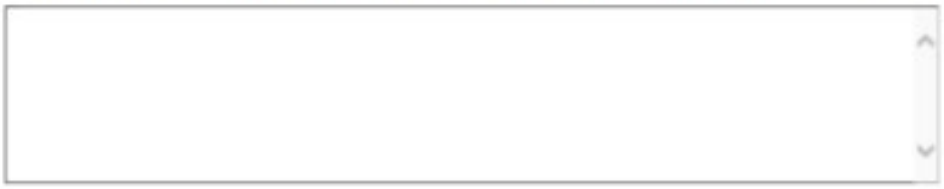

Please describe aspects within the equipment competency exam that you found helpful.

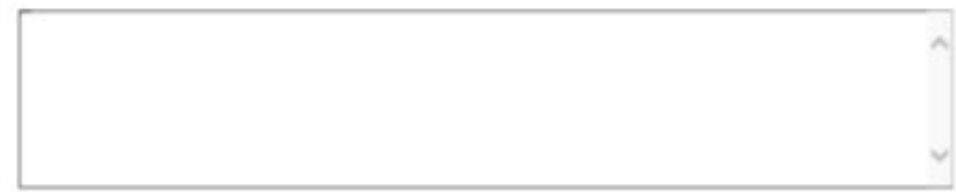

After completing the equipment competency exam please answer the following.

\begin{tabular}{|c|c|c|c|c|}
\hline & \multicolumn{4}{|c|}{$\begin{array}{l}\text { Please assess the following on } \\
\text { the exam. }\end{array}$} \\
\hline & $\begin{array}{l}\text { Highly } \\
\text { Oisagree }\end{array}$ & Disegree & Agree & $\begin{array}{l}\text { Highly } \\
\text { Agree }\end{array}$ \\
\hline $\begin{array}{l}\text { The entire } \\
\text { exam process } \\
\text { was clear. }\end{array}$ & 0 & 0 & 0 & 0 \\
\hline $\begin{array}{l}\text { Exam } \\
\text { explanation } \\
\text { document was } \\
\text { clear in the } \\
\text { instructions, } \\
\text { and } \\
\text { understancable. }\end{array}$ & 0 & 0 & 0 & 0 \\
\hline $\begin{array}{l}\text { Exam written } \\
\text { component } \\
\text { document was } \\
\text { clear, and } \\
\text { understandable. }\end{array}$ & 0 & 0 & 0 & 0 \\
\hline $\begin{array}{l}\text { Exam checklist } \\
\text { was a good } \\
\text { indicator of } \\
\text { completing and } \\
\text { using each } \\
\text { piece of } \\
\text { equipment. }\end{array}$ & 0 & 0 & 0 & 0 \\
\hline $\begin{array}{l}\text { The time } \\
\text { allotted for the } \\
\text { exam was } \\
\text { appropriate. }\end{array}$ & 0 & 0 & 0 & 0 \\
\hline
\end{tabular}

Please comment on your experience of taking the equipment competency exam.

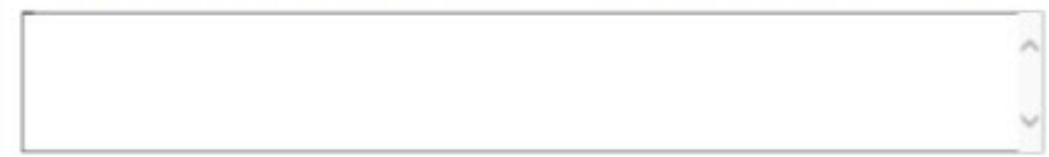


Please describe recommendations for equipment training for future FCS 384 students.

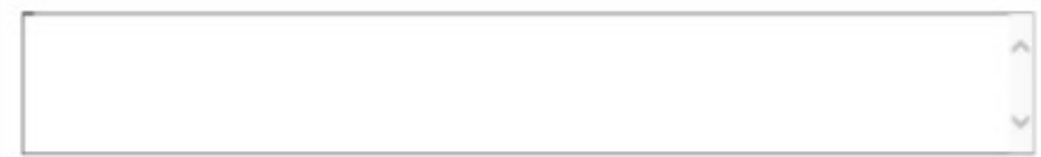

Please comment on recommendations and changes for future equipment competency exam testing.

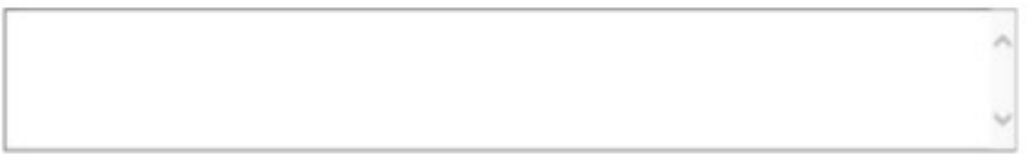

Thank you for participating in this project. Following completion, you will be redirected to a second survey. You will be asked to enter your name and e-mail address to receive. FCS 384 class credit for participation in this activity. All survey responses are anonymous. Your name will not be linked to the previous responses. 
Intervention 3 - Post- Practice Lab and Training Survey

Default Question Block

Please reflect on your current knowledge, competence, and comfort level related to working with foodservice equipment.

This project has been certified as exempt by the University of Idaho Institutional Review Board. All responses are anonymous.

Completion of the survey implies consent to participate and certifies you are at least 18 years of age.

Following the survey, you will be redirected to a second survey to enter your name and receive class credit for completing the activity.

Please assess knowledge after completing the equipment training and practice lab. Please consider the type of equipment and not the specific brand. 


\begin{tabular}{|c|c|c|c|c|}
\hline & \multicolumn{4}{|c|}{$\begin{array}{l}\text { Please asses knowledge after completing the equipment } \\
\text { training and practice lab. }\end{array}$} \\
\hline & $\begin{array}{c}\text { Not } \\
\text { knowledgeable }\end{array}$ & $\begin{array}{l}\text { Somewhat } \\
\text { knowledgeable }\end{array}$ & Knowledgeable & $\begin{array}{c}\text { Highly } \\
\text { knowledgeable }\end{array}$ \\
\hline $\begin{array}{l}\text { Alto-Sham } \\
\text { Combination } \\
\text { OverVSteamer }\end{array}$ & $\circ$ & $\circ$ & $\circ$ & $\circ$ \\
\hline $\begin{array}{l}\text { Alto-Sham } \\
\text { Cook Hold } \\
\text { Smoke Oven }\end{array}$ & $\circ$ & $\circ$ & $\circ$ & $\circ$ \\
\hline $\begin{array}{l}\text { Amana } \\
\text { Microwave }\end{array}$ & $\circ$ & $\circ$ & $\circ$ & $\circ$ \\
\hline $\begin{array}{l}\text { Blodgett } \\
\text { Convection } \\
\text { Oven } \\
\text { ZephaireE }\end{array}$ & $\circ$ & $\circ$ & 0 & 0 \\
\hline Globe Slicer & $\circ$ & $\circ$ & $\circ$ & $\circ$ \\
\hline $\begin{array}{l}\text { Groen Steam } \\
\text { Jacketed } \\
\text { Kettle }\end{array}$ & 0 & $\circ$ & $\circ$ & $\circ$ \\
\hline $\begin{array}{l}\text { Groen Tilting } \\
\text { Braising Pan }\end{array}$ & 0 & $\circ$ & 0 & $\circ$ \\
\hline $\begin{array}{l}\text { Hobart } 20 \\
\text { Quart Mixer }\end{array}$ & $\circ$ & $\circ$ & $\circ$ & o \\
\hline $\begin{array}{l}\text { Hobart } 60 \\
\text { Quart Mixer }\end{array}$ & $\circ$ & $\circ$ & $\circ$ & ० \\
\hline $\begin{array}{l}\text { Hobart } \\
\text { Dishwasher } \\
\text { AM15 }\end{array}$ & $\circ$ & $\circ$ & $\circ$ & 0 \\
\hline $\begin{array}{l}\text { Menumaster } \\
\text { High Speed } \\
\text { Combi Oven }\end{array}$ & $\circ$ & $\circ$ & $\circ$ & $\circ$ \\
\hline $\begin{array}{l}\text { Robot Coupe } \\
\text { Dice }\end{array}$ & $\circ$ & $\circ$ & $\circ$ & $\circ$ \\
\hline $\begin{array}{l}\text { Vulcan } \\
\text { Endurance / } \\
\text { Wolf } \\
\text { Challenger } \\
\text { Range }\end{array}$ & $\circ$ & $\circ$ & $\circ$ & 0 \\
\hline $\begin{array}{l}\text { Vulcan } \\
\text { Salamander }\end{array}$ & 0 & $\circ$ & $\circ$ & $\circ$ \\
\hline
\end{tabular}

Please assess competence (skill level) after completing the equipment training and practice lab.. Please consider the type of equipment and not the specific brand. 


\begin{tabular}{l|c} 
& $\begin{array}{c}\text { Please asses competence after completing the } \\
\text { equipment training and practice lab. } \\
\text { Not Somewhat }\end{array}$ \\
Competent Competent Competent & $\begin{array}{c}\text { Highly } \\
\text { Competent }\end{array}$ \\
\hline Alto-Sham & \\
Combination & \\
OverVSteamer & \\
Alto-Sham & \\
Cook Hold & \\
Smoke Oven & \\
Amana & \\
Microwave & \\
Blodgett & \\
Convection & \\
Oven & \\
ZephaireE & \\
Globe Slicer & \\
Groen Steam \\
Jacketed \\
Kettle \\
Groen Tilting \\
Braising Pan \\
Hobart 20 \\
Quart Mixer \\
Hobart 60 \\
Quart Mixer \\
Hobart \\
Dishwasher \\
AM15
\end{tabular}

Please assess comfort level in using the equipment after completing the equipment training and practice lab. Please consider the type of equipment and not the specific brand. 


\begin{tabular}{l|c} 
& $\begin{array}{c}\text { Please asses comfort level after completing the } \\
\text { equipment training and practice lab. }\end{array}$ \\
Not $\begin{array}{c}\text { Somewhat } \\
\text { Comfortable Comfortable Comfortable } \\
\text { Comfortable }\end{array}$ \\
Alto-Sham \\
Combination \\
OvenSteamer \\
Alto-Sham \\
Cook Hold \\
Smoke Oven \\
Amana \\
Microwave \\
Blodgett \\
Convection \\
Oven \\
ZephaireE \\
Globe Slicer \\
Groen Steam \\
Jacketed \\
Kettle \\
Groen Tilting \\
Braising Pan \\
Hobart 20
\end{tabular}

Please assess confidence level in being able to train someone on the equipment after completing the equipment training and practice lab. Please consider the type of equipment and not the specific brand. 


\begin{tabular}{|c|c|c|c|c|}
\hline & \multicolumn{4}{|c|}{$\begin{array}{c}\text { Please asses confident level after } \\
\text { completing the equipment training and } \\
\text { practice lab. }\end{array}$} \\
\hline & $\begin{array}{c}\text { Not } \\
\text { Confident }\end{array}$ & $\begin{array}{l}\text { Somewhat } \\
\text { Confident }\end{array}$ & Confident & $\begin{array}{l}\text { Highly } \\
\text { Confident }\end{array}$ \\
\hline $\begin{array}{l}\text { Alto-Sham } \\
\text { Combination } \\
\text { OverVSteamer }\end{array}$ & $\circ$ & $\circ$ & $\circ$ & $\circ$ \\
\hline $\begin{array}{l}\text { Alto-Sham } \\
\text { Cook Hold } \\
\text { Smoke Oven }\end{array}$ & $\circ$ & $\circ$ & $\circ$ & $\circ$ \\
\hline $\begin{array}{l}\text { Amana } \\
\text { Microwave }\end{array}$ & $\circ$ & $\circ$ & $\circ$ & $\circ$ \\
\hline $\begin{array}{l}\text { Blodgett } \\
\text { Convection } \\
\text { Oven } \\
\text { ZephaireE }\end{array}$ & $\circ$ & $\circ$ & $\circ$ & $\circ$ \\
\hline Globe Slicer & $\circ$ & $\circ$ & $\circ$ & $\circ$ \\
\hline $\begin{array}{l}\text { Groen Steam } \\
\text { Jacketed } \\
\text { Kettle }\end{array}$ & $\circ$ & $\circ$ & $\circ$ & $\circ$ \\
\hline $\begin{array}{l}\text { Groen Tilting } \\
\text { Braising Pan }\end{array}$ & 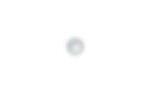 & $\circ$ & 0 & $\circ$ \\
\hline $\begin{array}{l}\text { Hobart } 20 \\
\text { Quart Mixer }\end{array}$ & $\circ$ & $\circ$ & o & $\circ$ \\
\hline $\begin{array}{l}\text { Hobart } 60 \\
\text { Quart Mixer }\end{array}$ & $\circ$ & $\circ$ & ○ & $\circ$ \\
\hline $\begin{array}{l}\text { Hobart } \\
\text { Dishwasher } \\
\text { AM15 }\end{array}$ & $\circ$ & 0 & $\circ$ & $\circ$ \\
\hline $\begin{array}{l}\text { Menumaster } \\
\text { High Speed } \\
\text { Combi Oven }\end{array}$ & $\circ$ & 0 & $\circ$ & $\circ$ \\
\hline $\begin{array}{l}\text { Robot Coupe } \\
\text { Dice }\end{array}$ & $\circ$ & $\circ$ & o & $\circ$ \\
\hline $\begin{array}{l}\text { Vulcan } \\
\text { Endurance / } \\
\text { Wolf } \\
\text { Challenger } \\
\text { Range }\end{array}$ & $\circ$ & $\circ$ & $\circ$ & 0 \\
\hline $\begin{array}{l}\text { Vulcan } \\
\text { Salamander }\end{array}$ & 0 & 0 & 0 & 0 \\
\hline
\end{tabular}

Please rank in order of your competency, by dragging the number to the equipment name. Number 1 would be the equipment you feel the most competent using and number 14 the equipment you feel the least competent using. Please consider the type of equipment and 
not the specific brand.

- Alto-Sham Combination Oven/Steamer

- Alto-Sham Cook Hold Smoke Oven

- Amana Microwave

- Blodgett Convection Oven ZephaireE

- Globe Slicer

- Groen Steam Jacketed Kettle

- Groen Tilting Braising Pan

- Hobart 20 Quart Mixer

- Hobart 60 Quart Mixer

- Hobart Dishwasher AM15

- Menumaster High Speed Combi Oven

- Robot Coupe Dice

- Vulcan Endurance / Wolf Challenger Range

- Vulcan Salamander

Please describe areas of foodservice equipment use in which you do not feel knowledgeable, confident, or comfortable.

Please describe aspects within the equipment training that you found helpful. 
Please describe aspects within the equipment practice lab that you found helpful.

After completing the equipment training and practice lab please answer the following.

\begin{tabular}{l|l} 
& $\begin{array}{c}\text { Please assess the following. } \\
\text { Highly } \\
\text { Disagree }\end{array}$ \\
The training & \\
was detailed \\
and clear. \\
Small size \\
training groups \\
benefited my \\
learning of the \\
equipment. \\
$\begin{array}{l}\text { The training } \\
\text { Agree }\end{array}$ \\
note sheet was \\
helpful during \\
the training and \\
practice lab. \\
The time \\
allotted for the \\
training was \\
appropriate. \\
The time \\
allotted for the \\
practice lab \\
was \\
appropriate.
\end{tabular}

Please comment on your equipment training experience. 
Please describe recommendations and changes for the equipment practice labs for future FCS 384 students.

Thank you for participating in this project. Following completion, you will be redirected to a second survey. You will be asked to enter your name and e-mail address to receive FCS 384 class credit for participation in this activity. All survey responses are anonymous. Your name will not be linked to the previous responses. 
Intervention 3 - Retrospective Pre- and Post- Intervention Survey

Default Question Block

Please reflect on your knowledge, competence, and comfort level related to working with foodservice equipment both currently and prior to beginning FCS 384 .

This project has been certified as exempt by the University of Idaho Institutional Review Board. All responses are anonymous. Completion of the survey implies consent to participate and certifies you are at least 18 years of age.

Following the survey, you will be redirected to a second survey to enter your name and receive class credit for completing the activity.

Prior to FCS 384 please check all the equipment that you have used before. If you have used the type of equipment before but from a different company (different brand), you can still check the box.

E. Alto-Sham Combination OvervSteamer

Groen Steam Jacketed Kettle

E Menumaster High Speed Combi Oven

alto-Sham Cook Hold Smoke Oven

c Groen Tilting Braising Pan

Robot Coupe Dice

Emana Microwave

CHobart 20 Quart Mixer

Blodgett Corwection Oven ZephaireE

E Hobart 60 Quart Mixer

E Vulcan Endurance / Woll Challenger Range

Elobe Slicer

E Hobart Distwasher AM15

Please assess knowledge prior to FCS 384 and after the competency exam. Please consider the type of equipment and not the specific brand. 


\begin{tabular}{|c|c|c|c|c|c|c|c|c|}
\hline & \multicolumn{4}{|c|}{$\begin{array}{l}\text { Please asses knowledge prior to beginning the FCS } 384 \\
\text { course. }\end{array}$} & \multicolumn{4}{|c|}{$\begin{array}{l}\text { Please assess knowledge after completing the equipment: } \\
\text { competency exam. }\end{array}$} \\
\hline & $\begin{array}{c}\text { Not } \\
\text { knowledgeable }\end{array}$ & $\begin{array}{c}\text { Somewhat } \\
\text { knowledgeable }\end{array}$ & Knowledgeable & $\begin{array}{c}\text { Highly } \\
\text { knowledgeable }\end{array}$ & $\begin{array}{c}\text { Not } \\
\text { knouledgeable }\end{array}$ & $\begin{array}{l}\text { Somewhat } \\
\text { knowledgeable }\end{array}$ & Knowledgeable & $\begin{array}{c}\text { Highly } \\
\text { knowiadgeable }\end{array}$ \\
\hline $\begin{array}{l}\text { Alto-Sham } \\
\text { Combination } \\
\text { Oven'Steamer }\end{array}$ & $\circ$ & $\circ$ & 0 & $\circ$ & $\circ$ & $\circ$ & 0 & $\circ$ \\
\hline $\begin{array}{l}\text { Alto-Sham } \\
\text { Cook Hold } \\
\text { Smoke Oven }\end{array}$ & $\circ$ & - & e & - & $\circ$ & $\circ$ & o & $\circ$ \\
\hline $\begin{array}{l}\text { Amana } \\
\text { Microwave }\end{array}$ & $\circ$ & - & e & - & e & $\circ$ & $\theta$ & $\circ$ \\
\hline $\begin{array}{l}\text { Blodgett } \\
\text { Corvection } \\
\text { Oven } \\
\text { ZephaireE }\end{array}$ & $\circ$ & $\circ$ & e & $\circ$ & $\circ$ & $\circ$ & e & $\circ$ \\
\hline Globe Slicer & e & 。 & e & e & e & 。 & o & 。 \\
\hline $\begin{array}{l}\text { Groen Steam } \\
\text { Jacketed } \\
\text { Kettle }\end{array}$ & $\circ$ & $\circ$ & $\circ$ & $\circ$ & $\circ$ & $\circ$ & e & $\circ$ \\
\hline $\begin{array}{l}\text { Groen Tilting } \\
\text { Braising Pan }\end{array}$ & $\circ$ & e & $\theta$ & - & e & - & e & e \\
\hline $\begin{array}{l}\text { Hobart } 20 \\
\text { Quart Mixer }\end{array}$ & $\circ$ & - & $\circ$ & 。 & 。 & $\circ$ & $\circ$ & - \\
\hline $\begin{array}{l}\text { Hobart } 60 \\
\text { Quart Mixer }\end{array}$ & e & - & 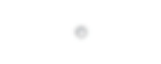 & - & $\circ$ & 。 & $\circ$ & e \\
\hline $\begin{array}{l}\text { Hobart } \\
\text { Dishwasher } \\
\text { AM15 }\end{array}$ & e & - & 0 & - & e & 。 & $\circ$ & $\circ$ \\
\hline $\begin{array}{l}\text { Merumaster } \\
\text { High Speed } \\
\text { Combi Oven }\end{array}$ & - & - & $\theta$ & 。 & 。 & 。 & $\circ$ & - \\
\hline $\begin{array}{l}\text { Robot Coupe } \\
\text { Dice }\end{array}$ & - & $\circ$ & $\circ$ & - & 。 & . & o & $\circ$ \\
\hline $\begin{array}{l}\text { Vulcan } \\
\text { Endurance / } \\
\text { Wolf } \\
\text { Challenger } \\
\text { Range }\end{array}$ & e & - & e & - & e & - & o & 。 \\
\hline $\begin{array}{l}\text { Vulcan } \\
\text { Salamander }\end{array}$ & $\circ$ & $\circ$ & $\circ$ & 。 & $\circ$ & $\circ$ & $\circ$ & $\circ$ \\
\hline
\end{tabular}

Please assess competence (skill level) prior to FCS 384 and after the competency exam. Please consider the type of equipment and not the specific brand. 


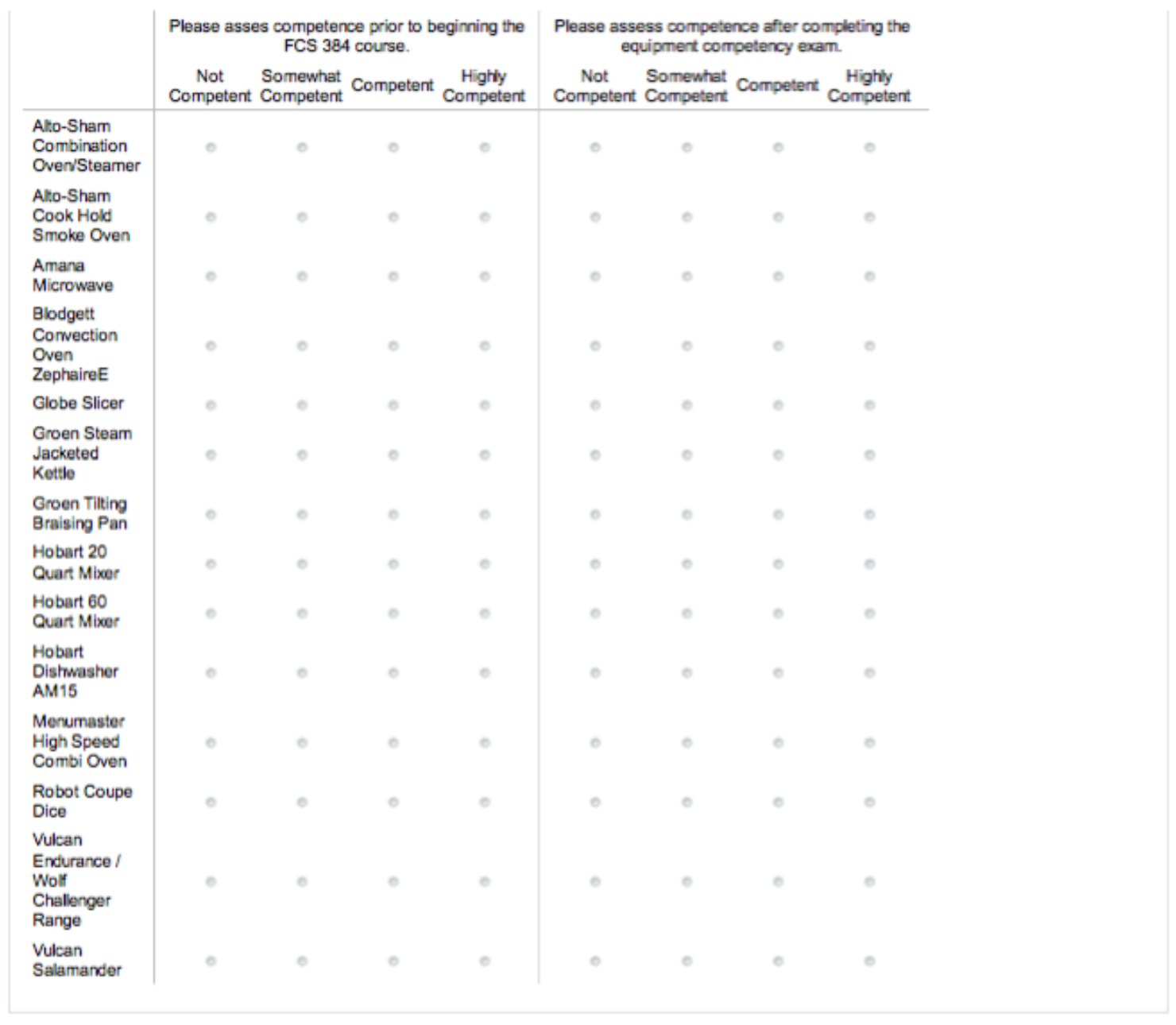

Please assess comfort level in using the equipment prior to FCS 384 and after the competency exam. Please consider the type of equipment and not the specific brand. 


\begin{tabular}{|c|c|c|c|c|c|c|c|c|}
\hline & \multicolumn{4}{|c|}{$\begin{array}{l}\text { Please asses comfort level prior to beginning the FCS } \\
\qquad 384 \text { course. }\end{array}$} & \multicolumn{4}{|c|}{$\begin{array}{l}\text { Please assess comfort level after completing the } \\
\text { equipment competency exam. }\end{array}$} \\
\hline & $\begin{array}{l}\text { Not } \\
\text { Comfortable }\end{array}$ & $\begin{array}{l}\text { Somewhat } \\
\text { Comfortable }\end{array}$ & Comfortable & $\begin{array}{c}\text { Highly } \\
\text { Comfortable }\end{array}$ & $\begin{array}{c}\text { Not } \\
\text { Comfortable }\end{array}$ & $\begin{array}{l}\text { Somewhat } \\
\text { Comfortable }\end{array}$ & Comfortable & $\begin{array}{l}\text { Highly } \\
\text { Comfortable }\end{array}$ \\
\hline $\begin{array}{l}\text { Alto-Sham } \\
\text { Combination } \\
\text { Over/Steamer }\end{array}$ & $\circ$ & $\circ$ & $\circ$ & $\circ$ & - & - & e & - \\
\hline $\begin{array}{l}\text { Al:o-Sham } \\
\text { Cook Hold } \\
\text { Smoke Oven }\end{array}$ & $\circ$ & $\circ$ & $\circ$ & 。 & $\circ$ & o & e & $\circ$ \\
\hline $\begin{array}{l}\text { Amana } \\
\text { Microwave }\end{array}$ & $\circ$ & - & $\circ$ & e & - & e & o & $\circ$ \\
\hline $\begin{array}{l}\text { Blodgett } \\
\text { Corvection } \\
\text { Oven } \\
\text { ZephaireE }\end{array}$ & 。 & $\circ$ & - & $\circ$ & 。 & o & o & 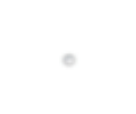 \\
\hline Globe Slicer & - & $\circ$ & 。 & $\circ$ & - & - & e & e \\
\hline $\begin{array}{l}\text { Groen Steam } \\
\text { Jacketed } \\
\text { Kottle }\end{array}$ & 0 & $\circ$ & e & e & - & e & e & 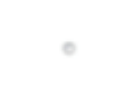 \\
\hline $\begin{array}{l}\text { Groen Titting } \\
\text { Braising Pan }\end{array}$ & - & 。 & e & e & e & o & o & e \\
\hline $\begin{array}{l}\text { Hobart } 20 \\
\text { Quart Mixer }\end{array}$ & $\circ$ & $\circ$ & $\circ$ & $\circ$ & $\circ$ & $\circ$ & 0 & e \\
\hline $\begin{array}{l}\text { Hobart } 60 \\
\text { Quart Mixer }\end{array}$ & 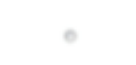 & - & e & e & e & e & o & 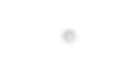 \\
\hline $\begin{array}{l}\text { Hobart } \\
\text { Dishwasher } \\
\text { AM15 }\end{array}$ & e & 。 & 。 & e & $\circ$ & e & e & e \\
\hline $\begin{array}{l}\text { Merumaster } \\
\text { High Speed } \\
\text { Combi Oven }\end{array}$ & $\circ$ & 。 & $\circ$ & $\circ$ & $\circ$ & o & 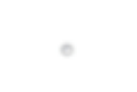 & $\circ$ \\
\hline $\begin{array}{l}\text { Robot Coupe } \\
\text { Dice }\end{array}$ & $\circ$ & $\circ$ & e & e & e & o & o & e \\
\hline $\begin{array}{l}\text { Vulcan } \\
\text { Endurance / } \\
\text { Wolf } \\
\text { Challenger } \\
\text { Range }\end{array}$ & $\circ$ & 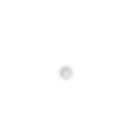 & e & $\circ$ & 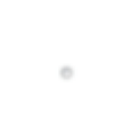 & e & e & e \\
\hline $\begin{array}{l}\text { Vulcan } \\
\text { Salamander }\end{array}$ & $\theta$ & - & e & e & $\circ$ & o & o & e \\
\hline
\end{tabular}

Please assess confidence level in being able to train someone on the equipment prior to FCS 384 and after the competency exam. Please consider the type of equipment and not the specific brand. 


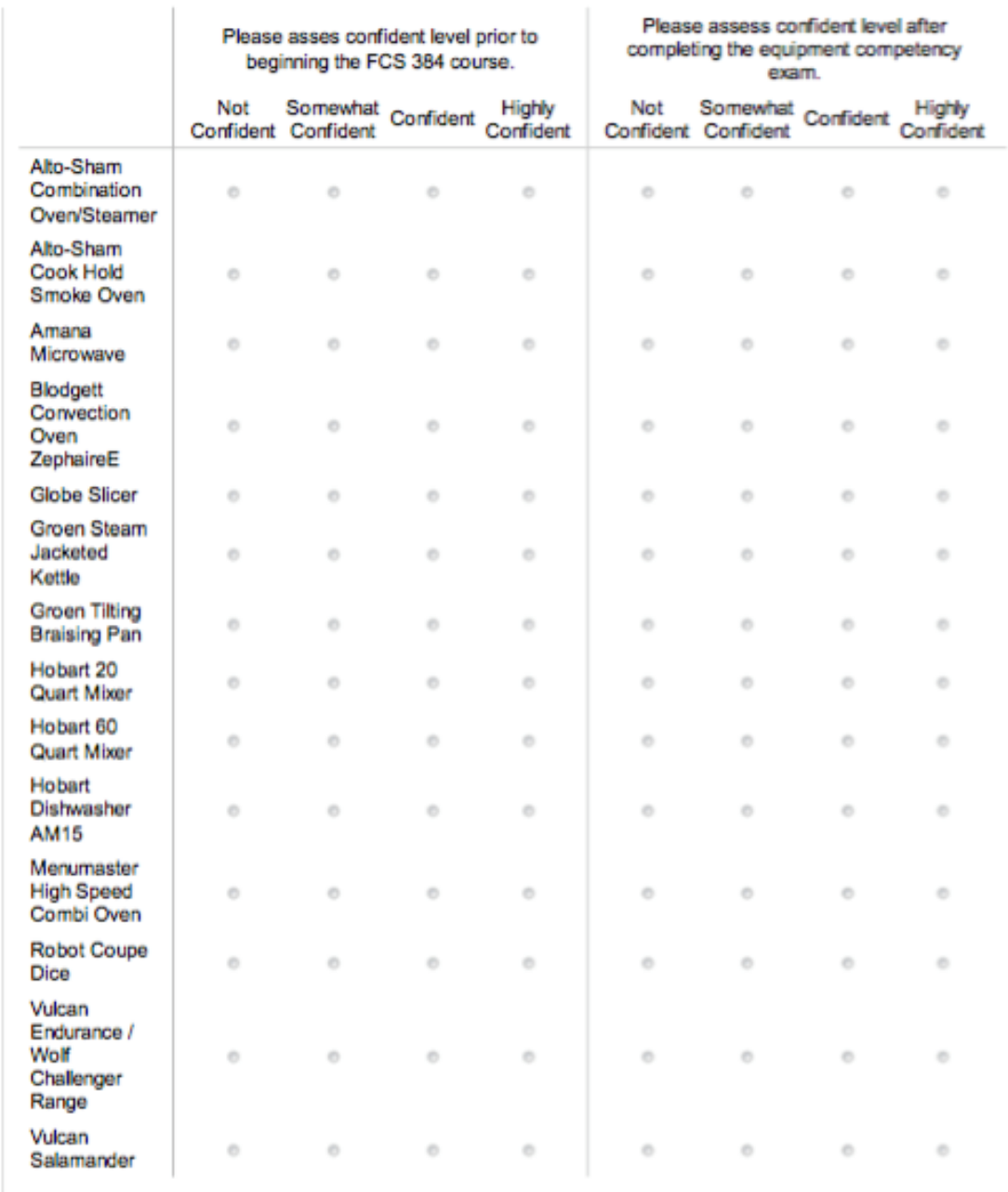

Please rank in order of your competency, by dragging the number to the equipment name. Number 1 would be the equipment you feel the most competent using and number 14 the equipment you feel the least competent using. Please consider the type of equipment and not the specific brand.

- Alto-Sham Combination Oven/Steame

- Alto-Sham Cook Hold Smoke Oven

- Amana Microwave

- Blodgett Convection Oven ZephaireE

- Globe Slicer

- Groen Steam Jacketed Kettle

- Groen Tilting Braising Pan

- Hobart 20 Quart Mixer

- Hobart 60 Quart Mixer 
- Hobart Dishwasher AM15

- Menumaster High Speed Combi Oven

- Robot Coupe Dice

- Vulcan Endurance / Wolf Challenger Range

- Vulcan Salamander

Please describe areas of foodservice equipment use in which you do not feel knowledgeable, confident, or comfortable.

Please describe food service experiences and resources prior to the FCS 384 course that contributed to your knowledge, competence and comfort level using foodservice equipment.

Please describe aspects within the equipment competency exam that you found helpful.

After completing the equipment competency exam please answer the following. 


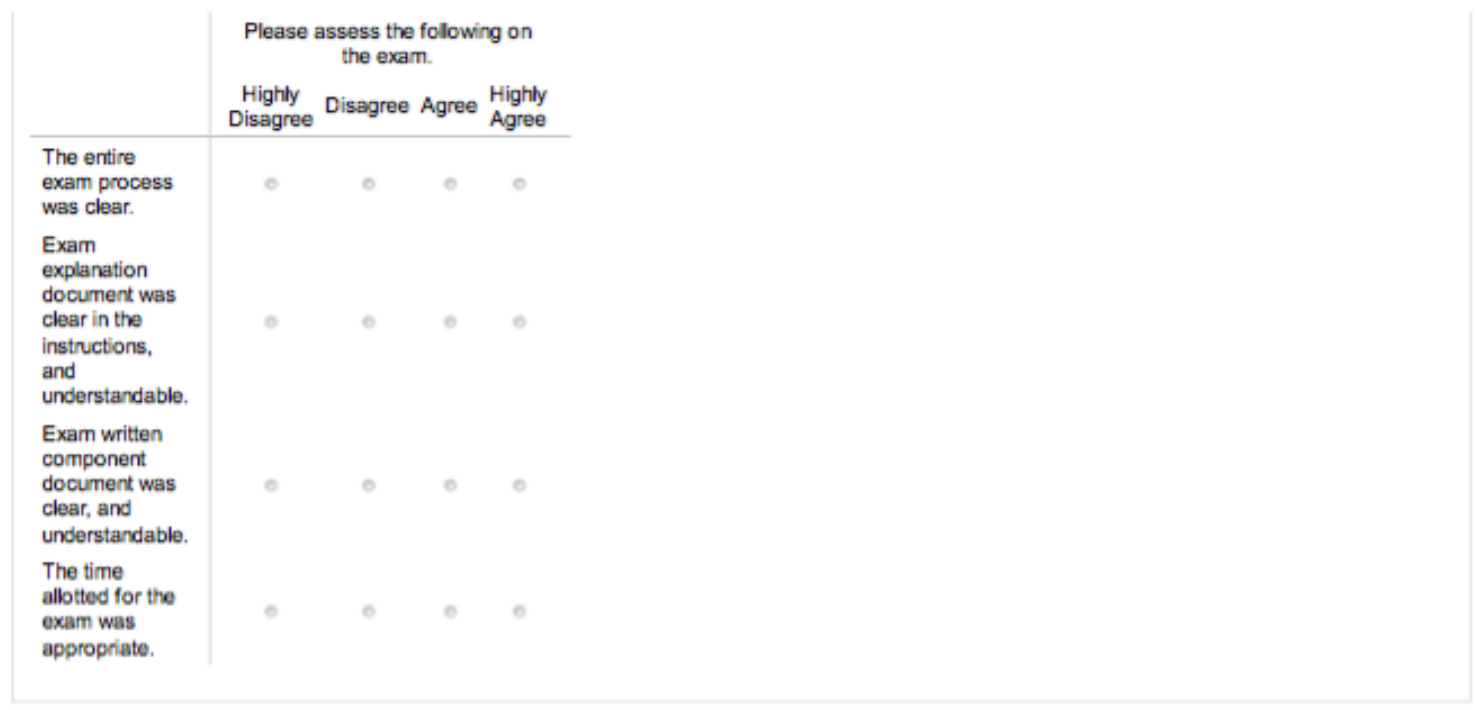

Please comment on your experience of taking the equipment competency exam.

Please describe recommendations for equipment training for future FCS 384 students.

Please comment on recommendations and changes for future equipment competency exam testing. 